\title{
The 5-HT1A receptor as a serotonergic target for neuroprotection in cerebral ischemia
}

\author{
Citation for published version (APA):
}

de Aguiar, R. P., Newman-Tancredi, A., Prickaerts, J., \& de Oliveira, R. M. W. (2021). The 5-HT1A receptor as a serotonergic target for neuroprotection in cerebral ischemia. Progress in NeuroPsychopharmacology \& Biological Psychiatry, 109, [110210]. https://doi.org/10.1016/j.pnpbp.2020.110210

Document status and date:

Published: 13/07/2021

DOI:

10.1016/j.pnpbp.2020.110210

Document Version:

Publisher's PDF, also known as Version of record

\section{Document license:}

Taverne

\section{Please check the document version of this publication:}

- A submitted manuscript is the version of the article upon submission and before peer-review. There can be important differences between the submitted version and the official published version of record.

People interested in the research are advised to contact the author for the final version of the publication, or visit the DOI to the publisher's website.

- The final author version and the galley proof are versions of the publication after peer review.

- The final published version features the final layout of the paper including the volume, issue and page numbers.

Link to publication

\footnotetext{
General rights rights.

- You may freely distribute the URL identifying the publication in the public portal. please follow below link for the End User Agreement:

www.umlib.nl/taverne-license

Take down policy

If you believe that this document breaches copyright please contact us at:

repository@maastrichtuniversity.nl

providing details and we will investigate your claim.
}

Copyright and moral rights for the publications made accessible in the public portal are retained by the authors and/or other copyright owners and it is a condition of accessing publications that users recognise and abide by the legal requirements associated with these

- Users may download and print one copy of any publication from the public portal for the purpose of private study or research.

- You may not further distribute the material or use it for any profit-making activity or commercial gain

If the publication is distributed under the terms of Article $25 \mathrm{fa}$ of the Dutch Copyright Act, indicated by the "Taverne" license above, 


\title{
The $5-\mathrm{HT}_{1 \mathrm{~A}}$ receptor as a serotonergic target for neuroprotection in cerebral ischemia
}

\author{
Rafael Pazinatto de Aguiar ${ }^{\mathrm{a}}$, Adrian Newman-Tancredi ${ }^{\mathrm{b}}$, Jos Prickaerts ${ }^{\mathrm{c}}$, \\ Rúbia Maria Weffort de Oliveira ${ }^{\text {a," }}$ \\ ${ }^{a}$ Department of Pharmacology and Therapeutics, State University of Maringá, Av. Colombo, 5790, CEP 87020-900, Maringá, Paraná, Brazil \\ ${ }^{\mathrm{b}}$ Neurolixis, Castres, France \\ ${ }^{c}$ Department of Psychiatry and Neuropsychology, School for Mental Health and Neuroscience, Maastricht University, Maastricht, The Netherlands
}

\section{A R T I C L E I N F O}

\section{Keywords:}

Cerebral ischemia

Serotonin

5- $\mathrm{HT}_{1 \mathrm{~A}}$ receptor

Neuroprotection

\begin{abstract}
A B S T R A C T
Cerebral ischemia due to stroke or cardiac arrest greatly affects daily functioning and the quality of life of patients and has a high socioeconomic impact due to the surge in their prevalence. Advances in the identification of an effective pharmacotherapy to promote neuroprotection and recovery after a cerebral ischemic insult are, however, limited. The serotonin $1 \mathrm{~A}\left(5-\mathrm{HT}_{1 \mathrm{~A}}\right)$ receptor has been implicated in the regulation of several brain functions, including mood, emotions, memory, and neuroplasticity, all of which are deleteriously affected by cerebral ischemia.

This review focuses on the specific roles and mechanisms of $5-\mathrm{HT}_{1 \mathrm{~A}}$ receptors in neuroprotection in experimental models of cerebral ischemia. We present experimental evidence that $5-\mathrm{HT}_{1 \mathrm{~A}}$ receptor agonists can prevent neuronal damage and promote functional recovery induced by focal and transient global ischemia in rodents. However, indiscriminate activation of pre-and postsynaptic by non-biased $5-\mathrm{HT}_{1 \mathrm{~A}}$ receptor agonists may be a limiting factor in the anti-ischemic clinical efficacy of these compounds since $5-\mathrm{HT}_{1 \mathrm{~A}}$ receptors in different brain regions can mediate diverging or even contradictory responses. Current insights are presented into the 'biased' 5$\mathrm{HT}_{1 \mathrm{~A}}$ post-synaptic heteroreceptor agonist NLX-101 (also known as F15599), a compound that preferentially and potently stimulates postsynaptic cortical pyramidal neurons without inhibiting firing of serotoninergic neurons, as a potential strategy providing neuroprotection in cerebral ischemic conditions.
\end{abstract}

\section{Introduction}

Cerebral ischemia resulting from stroke or cardiac arrest and is one of the leading causes of death and disability worldwide, presenting a significant global burden to patients, their relatives, and entire economies (Flynn et al., 2008; Benjamin et al., 2018; Rajsic et al., 2019). Patients who survive an ischemic cerebral insult are particularly vulnerable to the development of motor and cognitive impairments, depression, and anxiety disorders (Moulaert et al., 2010; Geri et al., 2014). Despite intense preclinical efforts, however, only limited advances have been made to develop effective therapies to promote recovery from cerebral ischemia (Ginsberg, 2009; Dirnagl and Endres, 2014).

Serotonin $5-\mathrm{HT}_{1 \mathrm{~A}}$ receptors have been implicated in the regulation of several brain functions such as motor function, body temperature, neuroendocrine activity, mood, emotion, and, memory. All these functions may be affected by cerebral ischemia. Besides, $5-\mathrm{HT}_{1 \mathrm{~A}}$ receptors have been a target for neuroprotection in animal models of cerebral ischemia. However, indiscriminate activation of pre and postsynaptic by $5-\mathrm{HT}_{1 \mathrm{~A}}$ receptor agonists may produce no therapeutic benefits in patients. The lack of receptor discrimination may be a limiting factor in the therapeutic efficacy of the agonists because $5-\mathrm{HT}_{1 \mathrm{~A}}$ receptors in different brain regions can mediate diverging or even contradictory responses. In this review, we present experimental evidence that $5-\mathrm{HT}_{1 \mathrm{~A}}$ receptor agonists can prevent neuronal damage and promote functional recovery induced by focal or transient global ischemia in rodents. We also discuss the biased $5-\mathrm{HT}_{1 \mathrm{~A}}$ agonist NLX-101 (also known as F15599), a compound that preferentially and potently stimulates postsynaptic cortical pyramidal neurons without inhibiting serotonin neuron firing (Newman-Tancredi et al., 2009; Lladó-Pelfort et al., 2010).

\footnotetext{
* Corresponding author.

E-mail address: rmmwoliveira@uem.br (R.M.W. Oliveira).
} 


\section{Serotonin and serotonin receptors}

Serotonin or 5-hydroxytryptamine (5-HT) is a monoamine which is widely distributed in the central nervous system. As a neurotransmitter, 5-HT is involved in almost every brain's physiological function and plays essential roles in hormonal control, sleep, body temperature, appetite, mood, motor activity, and cognition (Feijó Fde et al., 2010; David and Gardier, 2016; Haleem, 2019).

Serotonergic neurons arise from the brainstem raphe nuclei, i.e., the dorsal raphe nucleus (DRN), median raphe nucleus (MRN), and caudal raphe nucleus (CRN) (Bang et al., 2012). The DRN and MRN project serotonergic fibers through the medial forebrain bundle (MFB) to frontal areas, while the CRN innervates cerebellar and spinal targets (Jacobs and Azmitia, 1992; Gaspar and Lillesaar, 2012; Maddaloni et al., 2017). Most of the projections that reach the DRN come from the hypothalamus, medulla, cortex, and amygdala. The MRN receives projections from the amygdala, prefrontal cortex (PFC), and other cortical areas, and mainly from the hypothalamus and midbrain (Pollak Dorocic et al., 2014).

5-HT is synthesized in two steps from the essential amino acid Ltryptophan acquired from the diet. Tryptophan is hydroxylated at position 5 to 5-hydroxytryptophan by tryptophan hydroxylase (TPH) is the rate-limiting enzyme, and then decarboxylated by the amino acid Lamino-aromatic enzyme, to 5-HT (Walther et al., 2003). Two TPH isoforms have been identified: TPH1 which is expressed in non-neuronal cells such as enterochromaffin and mast cells (Fitzpatrick, 1999), and the TPH2 isoform which is expressed in the raphe nuclei and myenteric plexus (Walther et al., 2003). After synthesis, 5-HT storage occurs in vesicles present in presynaptic neurons. Once released in the synaptic cleft, 5-HT may act on pre-or postsynaptic serotonergic receptors. Subsequently, 5-HT is taken up through the serotonin transporter (SERT), into presynaptic neurons where it undergoes a degradation process by the monoamine oxidase enzyme (MAO) generating the 5-hydroxy indole acetic metabolite (5-HIAA) (David and Gardier, 2016). In addition to its release in projection areas, vesicular 5-HT release occurs locally in the DRN at somatic (Colgan et al., 2009), dendritic (Cornelisse et al., 2006; Colgan et al., 2012), and axonal sites (Bruns et al., 2000), where it modulates the activity of DRN neurons. Ultrastructural studies have found somatodendritic receptors at extrasynaptic sites where serotonergic transmission occurs by paracrine activation by low concentrations of transmitter out from synapses, i.e., via volume transmission (Bunin and Wightman, 1999; Courtney and Ford, 2016).

Serotonergic receptors are proteins that are bound to membranes and grouped into families according to their associated system of second messengers, their amino acid sequence, or their functional homology. The functional responses to 5-HT are mediated by 7 different families of receptors, designated $5-\mathrm{HT}_{1}$ to $5-\mathrm{HT}_{7}$, which are further divided into 15 subtypes (Hoyer et al., 1994; Bockaert et al., 2010; Hannon and Hoyer,
2008; Table 1). Except for the 5-HT 3 ionotropic receptor, all other 5-HT receptors are classical metabotropic G-protein coupled receptors (GPCR) which couple to canonical signaling pathways through $\mathrm{G} \alpha \mathrm{i}, \mathrm{G} \alpha \mathrm{s}$, and $\mathrm{G} \alpha \mathrm{q} / 11$ and elicit the expected second messenger cascades (Nichols and Nichols, 2008). The Goi-coupled serotonin receptors encompass the 5$\mathrm{HT}_{1}$ and $5-\mathrm{HT}_{5}$ types, leading to inhibition of adenylyl cyclase (AC) and a consequent decrease of cyclic adenosine monophosphate (cAMP) levels (Lin et al., 2002). The G $\alpha \mathrm{q} / 11$-coupled serotonin receptors include the $5-\mathrm{HT}_{2}$ receptor subtypes, which are linked to activation of phospholipase C (PLC), producing inositol trisphosphate (IP3) and diacylglycerol (DAG), ultimately leading to an increase in intracellular calcium $\left(\mathrm{Ca}^{++}\right.$) (Roth et al., 1998). 5- $\mathrm{HT}_{4}, 5-\mathrm{HT}_{6}$, and $5-\mathrm{HT}_{7}$ coupled to the stimulatory G protein ( $\mathrm{G} \alpha \mathrm{s})$ and stimulate AC and protein kinase A (PKA), leading to increased levels of cAMP (Polter and Li, 2010) (Table 1). Metabotropic 5-HT receptor function may also elicit noncanonical signals that can be either mediated by a host of alternative G-proteins or be G-protein-independent. G-protein independent signaling may involve $\beta$-arrestins which are associated with other signaling pathways such as the mitogen-activated protein kinases including extracellular signal-regulated kinase (ERK) (Schmid et al., 2008; McCorvy and Roth, 2015). These pathways can also be activated via G-protein mediated mechanisms. Arrestin has been associated with GPCR desensitization (Freedman and Lefkowitz, 1996) and internalization (Ferguson et al., 1996), indicating the clinical importance of this signaling pathway to tolerance development and therapeutic efficacy of drugs (Violin et al., 2014).

\section{The $5-\mathrm{HT}_{1 \mathrm{~A}}$ receptor}

The $5-\mathrm{HT}_{1}$ receptor family is divided into 6 subtypes: A, B, C, D, E, and $\mathrm{F}$ (Peroutka, 1988). Among all the subtypes, the $5-\mathrm{HT}_{1 \mathrm{~A}}$ receptor is most studied and characterized because of its involvement in the pathophysiology and treatment of several psychiatric and neurological conditions such as anxiety, depression, Parkinson's disease, and Alzheimer's disease (Pazos et al., 1985; Celada et al., 2013; Garcia-Garcia et al., 2014; Albert and Vahid-Ansari, 2019). The induction of adult neurogenesis by antidepressants and remodeling of corticolimbic circuits has also been related to the stimulation of $5-\mathrm{HT}_{1 \mathrm{~A}}$ receptors (Santarelli et al., 2003). Moreover, novel antidepressants and antipsychotics have begun to incorporate $5-\mathrm{HT}_{1 \mathrm{~A}}$ agonist activity to enhance their therapeutic efficacy. Clozapine and the more recent antipsychotics aripiprazole, brexpiprazole, perospirone, and cariprazine, for example, exhibit partial agonist properties at $5-\mathrm{HT}_{1 \mathrm{~A}}$ receptors and may alleviate a deficiency in dopaminergic transmission in frontocortical regions of schizophrenic patients, thus improving negative and cognitive symptoms. Further, $5-\mathrm{HT}_{1 \mathrm{~A}}$ receptor activation has been shown to reduce extrapyramidal symptoms induced by neuroleptics (for review see Newman-Tancredi and Kleven, 2011; Celada et al., 2013).

Table 1

Serotonin receptor types, subtypes, locations and signaling mechanisms in the CNS

\begin{tabular}{|c|c|c|c|c|c|}
\hline Receptor & Subtypes & Locations & $\begin{array}{l}\text { Signaling } \\
\text { mechanism }\end{array}$ & $\begin{array}{l}\text { Cellular } \\
\text { response }\end{array}$ & References \\
\hline $5-\mathrm{HT}_{1}$ & $\begin{array}{l}1 \mathrm{~A}, 1 \mathrm{~B}, 1 \mathrm{C} 1 \mathrm{D} \\
1 \mathrm{E}, 1 \mathrm{~F}\end{array}$ & $\begin{array}{l}\text { raphe nuclei, hippocampus, córtex, striatum, } \\
\text { amygdala, hypotalamus }\end{array}$ & $\begin{array}{l}\text { G } \alpha i / o ; \text { AC, PKA, } \\
\downarrow \text { cAMP }\end{array}$ & Inhibitory & $\begin{array}{l}\text { De Vivo and Maayani, 1986; Albert et al., 1990; Liu and } \\
\text { Albert, 1991; Albert and Vahid-Ansari, } 2019\end{array}$ \\
\hline $5-\mathrm{HT}_{2}$ & $2 \mathrm{~A}, 2 \mathrm{~B}, 2 \mathrm{C}$ & $\begin{array}{l}\text { raphe nuclei, hippocampus, córtex, striatum, } \\
\text { amygdala, hypotalamus }\end{array}$ & $\begin{array}{l}\text { G } \alpha q ; \text { PLC, } \uparrow \text { IP3 } \\
\text { and DAG }\end{array}$ & Excitatory & Roth et al., 1998; Xu and Pandey, 2000 \\
\hline $5-\mathrm{HT}_{3}$ & $3 \mathrm{~A}, 3 \mathrm{~B}$ & $\begin{array}{l}\text { hippocampus, córtex, striatum, amygdala, } \\
\text { dorsal vagal complex }\end{array}$ & $\begin{array}{l}\mathrm{Na}^{+}, \mathrm{K}^{+} \text {ion } \\
\text { channels }\end{array}$ & Excitatory & Pratt et al., 1990; Chameau and van Hooft, 2006 \\
\hline $5-\mathrm{HT}_{4}$ & & $\begin{array}{l}\text { hippocampus, córtex, striatum, amygdala, } \\
\text { basal ganglia }\end{array}$ & $\begin{array}{l}\text { G } \alpha s ; \mathrm{AC}, \mathrm{PKA}, \\
\uparrow \mathrm{cAMP}\end{array}$ & Excitatory & Eglen et al., 1995; Bockaert et al., 2004 \\
\hline $5-\mathrm{HT}_{5}$ & & Raphe nuclei & G $\alpha i / \mathrm{o}, \downarrow$ cAMP & Inhibitory & Nelson, 2004 \\
\hline $5-\mathrm{HT}_{6}$ & & $\begin{array}{l}\text { hippocampus, córtex, striatum, } \\
\text { amygdala, basal ganglia }\end{array}$ & $\begin{array}{l}\text { G } \alpha s ; \text { AC, PKA, } \uparrow \\
\text { cAMP }\end{array}$ & Excitatory & Woolley et al., 2004; Codony et al., 2010 \\
\hline $5-\mathrm{HT}_{7}$ & & $\begin{array}{l}\text { hippocampus, } \\
\text { suprachiasmatic nucleus }\end{array}$ & $\begin{array}{l}\text { G } \alpha s ; \mathrm{AC}, \mathrm{PKA}, \uparrow \\
\text { cAMP }\end{array}$ & Excitatory & Thomas and Hagan, 2004; Gellynck et al., 2013 \\
\hline
\end{tabular}

AC, adenylate cyclase; cAMP, cyclic Adenosine Monophosphate; DAG, Diacylglycerol; IP3, inositol trisphosphate; PKA protein kinase A; PLC, phospholipase C. 
5- $\mathrm{HT}_{1 \mathrm{~A}}$ receptors can be classified into two distinct populations: presynaptic autoreceptors, located in the soma and dendrites of serotonergic neurons in the raphe nuclei, and postsynaptic heteroreceptors, which exist in dendrites and cell bodies of target non-5-HT neurons in 5HT projecting areas (Fig. 1) (Verge et al., 1985; Riad et al., 2000; Palacios, 2016). At a presynaptic level, 5- $\mathrm{HT}_{1 \mathrm{~A}}$ receptor activation reduces the firing rate of raphe nuclei neurons, with a consequent decrease in the extracellular levels of 5-HT in its projection areas (Wang and Aghajanian, 1977; Verge et al., 1985; Sprouse and Aghajanian, 1986; Meller et al., 1990; Hjorth and Sharp, 1991). 5-HT HA $_{1 \mathrm{~A}}$ heteroreceptors are located in non-serotonergic neurons, primarily in limbic areas such as the PFC, amygdala, septum, and hippocampus (Albert and Vahid-Ansari, 2019), where they can mediate neuroprotective effects (Fig. 1). In these areas, $5-\mathrm{HT}_{1 \mathrm{~A}}$ receptors are expressed in the dendrites and soma of glutamatergic pyramidal neurons (Riad et al., 2000) and, axon terminals of GABAergic (Freund et al., 1990; Halasy et al., 1992) and cholinergic neurons (Cassel and Jeltsch, 1995). Typically, activation of heteroreceptors on distinct neurons reduces neuronal excitability and firing (Polter and Li, 2010). Finally, the presence of 5- $\mathrm{HT}_{1 \mathrm{~A}}$ receptors has been demonstrated in the cell body and processes of astrocytes (WhitakerAzmitia et al., 1992). 5- $\mathrm{HT}_{1 \mathrm{~A}}$ expression in astrocytes was related to neuroprotective effects in Parkinsonian mice (Miyazaki et al., 2013; Miyazaki and Asanuma, 2016) and gerbils with cerebral ischemia (Lee et al., 2015) by promoting astrocyte proliferation and upregulation of antioxidative molecules.

Multiple 5- $\mathrm{HT}_{1 \mathrm{~A}}$ receptor signaling pathways have been identified in heterologous systems, but only a few of these pathways have been studied in neuronal systems. In general, the primary coupling linkage of

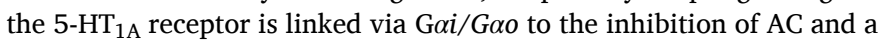
decrease in PKA activity (Fig. 2). 5- $\mathrm{HT}_{1 \mathrm{~A}}$ receptors also couple to ion channels, via $\mathrm{G} \beta / \gamma$ subunits, activating inward rectifying potassium channel (GIRK) to hyperpolarize membrane potential and inhibit voltage-dependent $\mathrm{Ca}^{++}$channels (VDCC) (Fig. 2) (Raymond et al., 1999; Albert and Vahid-Ansari, 2019). For other $5-\mathrm{HT}_{1 \mathrm{~A}}$ receptor-G protein interactions, the $\mathrm{G} \beta / \gamma$ complex is always released, which in turn can activate multiple effectors including the phosphorylated mitogen-activated protein kinase (MAPK), ERK1/2 and also PI3-kinase (PI3K)-Akt-GSK3 $\beta$ signaling pathways (Della Rocca et al., 1999). Differences in $5-\mathrm{HT}_{1 \mathrm{~A}}$ autoreceptor and heteroreceptor coupling to $\mathrm{G}$ proteins are believed to underlie different signaling and desensitization (Haleem, 2019). The autoreceptors are reported to mainly couple with $\mathrm{G} \alpha i$ while heteroreceptors are preferentially coupled to $\mathrm{G} \alpha o$ in the hippocampus and with both G $\alpha o$ and Goi in the cortex (Mannoury la Cour et al., 2006). Therefore, the signaling pathway associated with the 5$\mathrm{HT}_{1 \mathrm{~A}}$ receptor is probably determined by the precise signaling environment existing in a particular cell, even though the presence of other $\mathrm{G}$ proteins may redirect signal transduction to other existing pathways (Rojas and Fiedler, 2016).

A major pathway of the $5-\mathrm{HT}_{1 \mathrm{~A}}$ receptor coupled to $\mathrm{G} \beta / \gamma$ complex is the ERK1/2, pathway mediated by phosphorylated MAPK/ERK kinase. Hydrolysis of MAPK precedes the stimulation of the critical enzymes ERK1/2, which activates the transcription factor of the cAMP-responsive binding protein (CREB). CREB has been shown to regulate neuronal proliferation and survival, neurogenesis, and dendritic remodeling (Carlezon Jr et al., 2005; Blendy, 2006). 5- $\mathrm{HT}_{1 \mathrm{~A}}$ receptor coupling to ERK1/2 is observed in the hippocampal-derived cell lines with endogenous expression of 5- $\mathrm{HT}_{1 \mathrm{~A}}$ receptors (Adayev et al., 1999) as well as in hippocampal tissue (Mehta et al., 2007a). The 5-HT1A/CREB/ERK1/2 pathway seems to be important for neuronal protection (Albert and Vahid-Ansari, 2019). Direct stimulation of 5-HT $1 \mathrm{~A}$ receptor caused elevation in the expression of postsynaptic density protein (PSD)-95 and dendritic spine and synapse formation throughout sequential activation of MAPK isoenzymes ERK1/2 and protein kinase $\mathrm{C}$ alpha (PKC $\alpha$ ) in both a mouse neuron-derived cell line (HN2-5) and in organotypic hippocampal slice cultures from postnatal day 15 (P15) mice (Debata et al., 2010). The same pathway PKC $\alpha /$ ERK1/2 augmented PSD-95 and synaptogenesis in the hippocampus of in vivo mice (Mogha et al., 2012). These findings indicated that PKC $\alpha$ constitutes a direct substrate of ERK1/2 in neuronal cells and might have a role in the neuroprotection of hippocampal neurons (Mogha et al., 2012). However, the effects of 5-

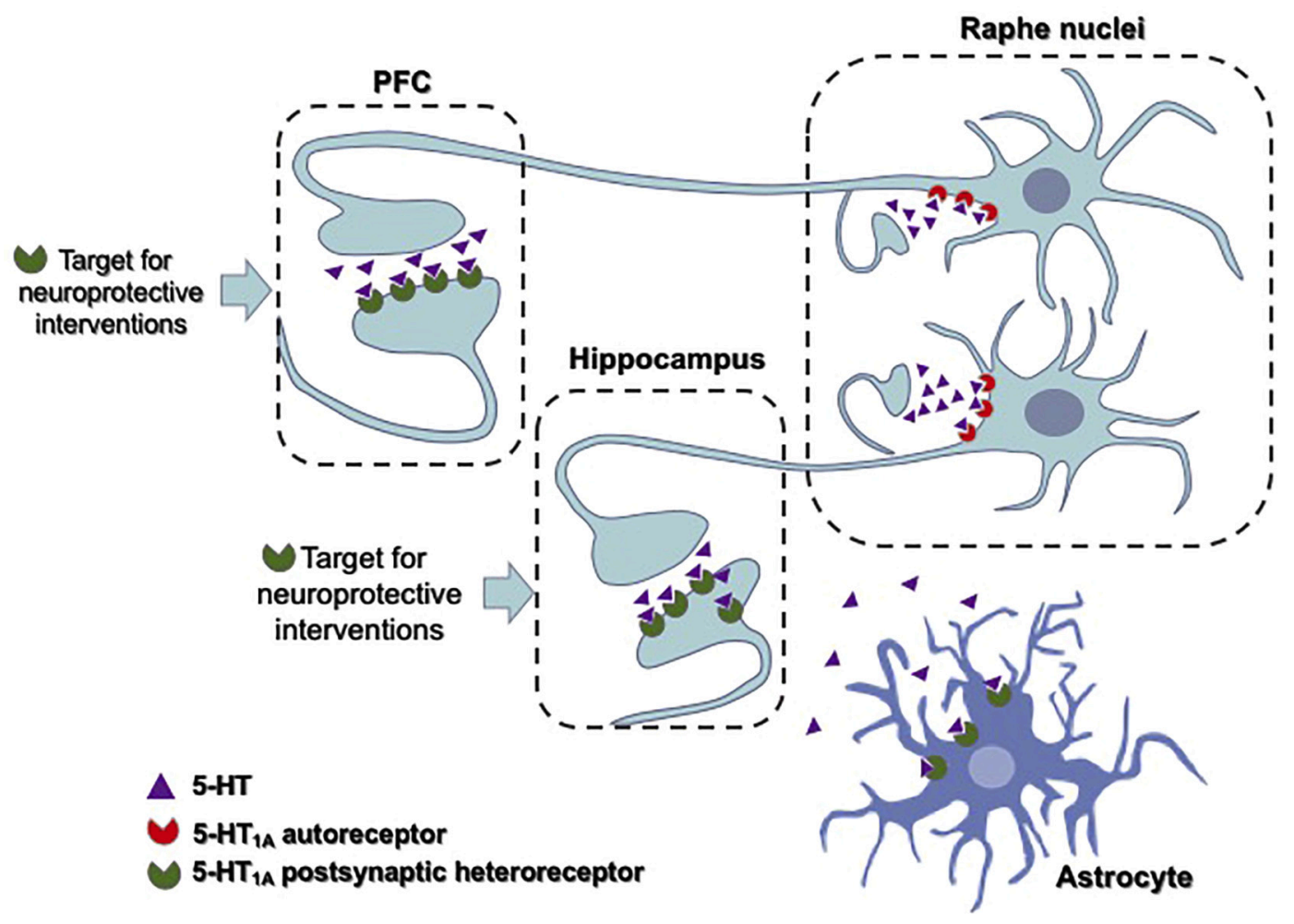

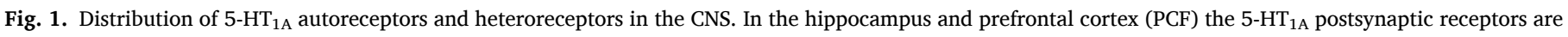
presented as targets for neuroprotective interventions. 


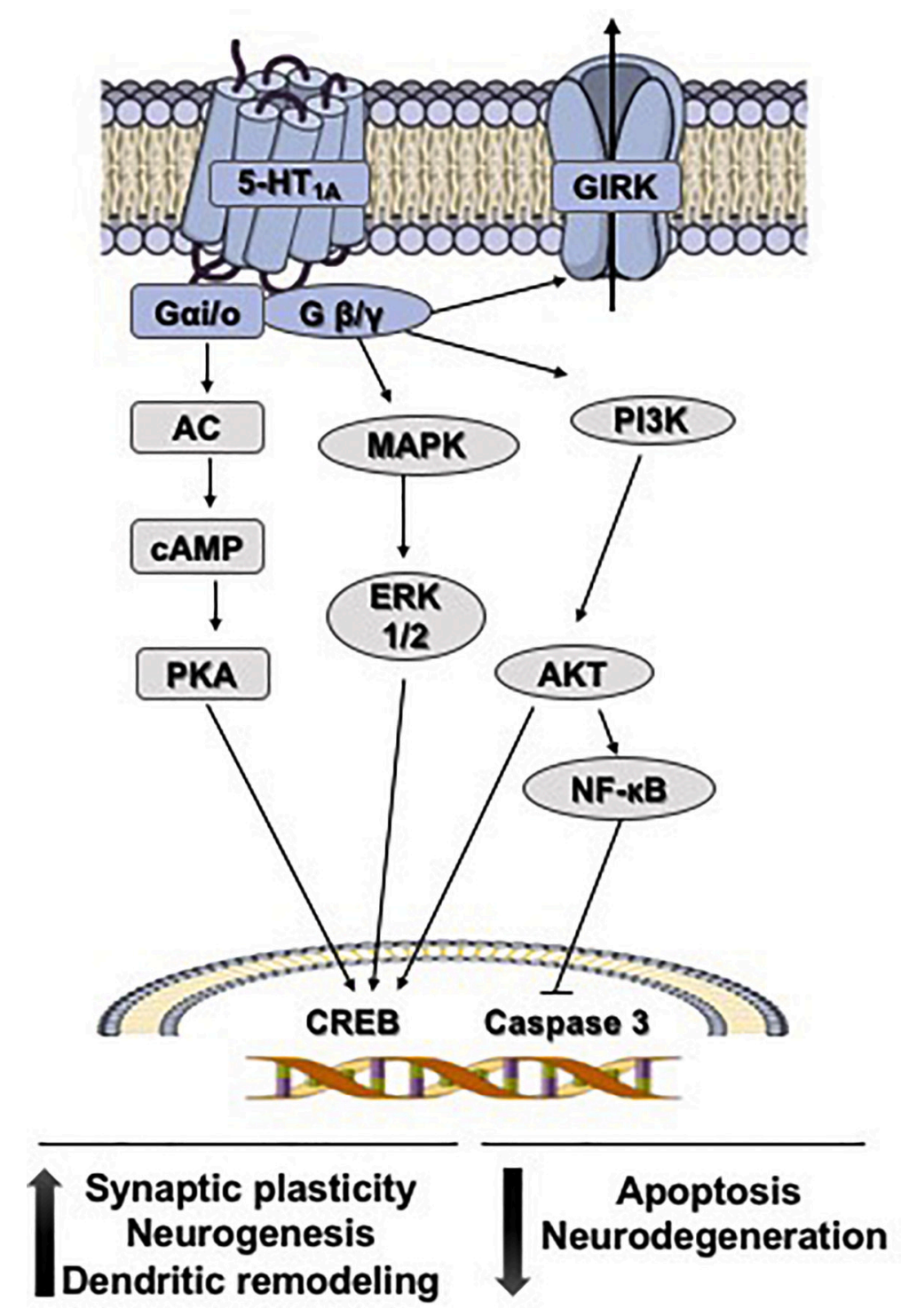

Fig. 2. Signaling transduction pathways linked to $5-\mathrm{HT}_{1 \mathrm{~A}}$ autoreceptors and/or postsynaptic heteroreceptors.

$\mathrm{HT}_{1 \mathrm{~A}}$ receptor activation of ERK on neurons vary and appear to depend on their location in different brain regions. For example, $5-\mathrm{HT}_{1 \mathrm{~A}}$ receptor activation inhibits ERK1/2 phosphorylation in RN46A cells, a model of serotonergic raphe nucleus neurons that express endogenous 5$\mathrm{HT}_{1 \mathrm{~A}}$ receptors (Kushwaha and Albert, 2005). Besides, endogenous 5$\mathrm{HT}_{1 \mathrm{~A}}$ receptors did not couple to activation of ERK1/2 in primary cultures of rat hippocampal neurons (Cowen et al., 2005).

The PI3K/Akt pathway has been found to confer neuroprotection by inhibiting apoptosis in several experimental conditions (Tamatani et al., 1998; Matsuzaki et al., 1999; Yamaguchi et al., 2001). Activation of PI3K/Akt pathway by $5-\mathrm{HT}_{1 \mathrm{~A}}$ receptor resulted in translocation of the nuclear transcription factor-kB (NF-kB) which was required for inhibiting caspase 3 activation in transfected Chinese hamster ovary cells (Hsiung et al., 2005). The PI3-K/Akt pathway has been implicated in the regulation of cell growth, survival, and proliferation as well as in synaptic plasticity (Kim et al., 2004). However, the exact mechanism of how $5-\mathrm{HT}_{1 \mathrm{~A}}$ receptors couple to the PI3K pathway in neurons is still unclear (Albert and Vahid-Ansari, 2019).

The signaling pathways associated with $5-\mathrm{HT}_{1 \mathrm{~A}}$ receptors are probably determined by the precise Goi/Goo isoform existing in cells and cascades involving $\mathrm{G} \beta / \gamma$ signaling. 5- $\mathrm{HT}_{1 \mathrm{~A}}$ receptor activation may impact neuronal plasticity and decrease neurodegeneration likely by modulation of MAPK/ERK and PI3K/Akt signaling pathways (Chilmonczyk et al., 2015; Rojas and Fiedler, 2016; Albert and Vahid-Ansari, 2019; Sharp and Barnes, 2020). Of note, those signaling pathways have been suggested to be involved in neuroprotective mechanisms including the stimulation of nuclear factor-kB (NF-kB), inhibition of caspase 3 , and increasing the expression of the antiapoptotic protein Bcl-2 (Chilmonczyk et al., 2015).

4. $5-\mathrm{HT}_{1 \mathrm{~A}}$ receptors as a potential target for neuroprotection in cerebral ischemia

\subsection{Cerebral ischemia}

Cerebral ischemia is one of the principal causes of death and disability worldwide and represents an increased economic burden due to treatment and post-ischemia care (Chamorro et al., 2016; Benjamin et al., 2018; Rajsic et al., 2019; Johnson et al., 2019). Cerebral ischemia occurs as a result of the transient or permanent reduction in the cerebral blood flow (CBF) in restricted brain regions (focal cerebral ischemia or stroke) or the whole brain (global cerebral ischemia). Focal cerebral ischemia (FCI) has been categorized as either ischemic or hemorrhagic. Ischemic stroke is caused by the interruption of CBF to the brain due to a 
thrombotic or embolic occlusion in a particular cerebral artery. Hemorrhagic strokes occur within the brain ruptures. Globally, ischemic stroke accounts for $87 \%$ of stroke cases and it is the third most frequent cause of death for people over 60 years old in developed countries. Hemorrhagic stroke accounts for the remaining $13 \%$ of patients (Chamorro et al., 2016; Johnson et al., 2019). According to a report from the Johnson et al. (2019) Lifetime Risk of Stroke Collaborators, the global lifetime risk of stroke from the age of 25 years onward was approximately $25 \%$ among both men and women (Johnson et al., 2019; GBD, 2016).

Prolonged circulatory deficits may induce dramatic neuronal damage, leading to a broad range of neuropsychological and behavioral dysfunctions, such as motor impairments, cognitive deficits, and emotional symptoms (Anderson and Arciniegas, 2010). Motor deficits are the most common symptom after stroke and are present in up to $77 \%$ of the patients (Lawrence et al., 2001). Studies on cognitive impairment after cerebral ischemia have reported rates ranging from $35 \%$ to $87 \%$ (Hoffmann et al., 2010; van Rooij et al., 2014; Delavaran et al., 2017). Anxiety and post-stroke depression range from 29\% to 52\% (Ayerbe et al., 2013; Hackett and Pickles, 2014; Knapp et al., 2017). The neuropsychiatric sequelae of cerebral ischemia are disabling and can have a negative influence on recovery, reduce the quality of life, and lead to exhaustion of the caregivers.

In general, stroke is characterized by an infarcted core, where cell death occurs within minutes after arterial occlusion and the periinfarcted region surrounding the infarction named penumbra where there is a partial reduction in blood supply; this region represents an area to which therapeutic neuroprotective interventions can be directed (Povroznik et al., 2018). The nature and severity of FCI consequences depend mainly on the location and extent of the injury.

Experimentally, FCI can be modeled through transient or permanent occlusion of the middle cerebral artery (MCA) in mice or rats. MCA occlusion (MCAo) models have been used extensively because they reproduce the pattern of ischemic cerebral damage and the functional disabilities such as neurological deficits, including sensorimotor changes which are also often observed in many human stroke patients (Traystman, 2003; Hermann et al., 2019). In general, MCAo results in a significant reduction of $\mathrm{CBF}$ in both striatum and cortex. However, the degree and distribution of blood flow reduction depend on the duration of MCAo, the site of occlusion along with the MCA, and the amount of collateral blood flow into the MCA territory (Traystman, 2003; Gennaro et al., 2019). These factors determine the size of the lesion. Considerable variability in the extension of infarct size and behavioral outcomes have been recurrent findings with this model and compromised in part its potential in preclinical studies (Bardutzky et al., 2005; Senda et al., 2011).

Transient global cerebral ischemia (TGCI) results from unexpected reversible cardiac arrest, severe respiratory arrest, gas poisoning, perinatal asphyxia, and diagnostic and surgical procedures. Patients that survive TGCI may experience a wide range of long-term dysfunctions, the most prominent of which are cognitive deficits, attention deficits, verbal communication deficiency, spatial/temporal disorientation, impaired decision-making, anxiety, and depression (Anderson and Arciniegas, 2010). TGCI can be modeled through bilateral typical carotid artery occlusion (BCCAO) in mice and Mongolian gerbils and via two vessels (2-VO) or four-vessel occlusion (4-VO) in rats (León-Moreno et al., 2020). Usually, TGCI affects areas of the forebrain, such as the highly vulnerable hippocampal pyramidal neurons (CA1 and CA3 regions), the medium-sized dorsoventral striatum neurons, and the pyramidal neurons in the PFC (Raval et al., 2009; Li et al., 2011; Khodanovich and Kisel, 2015). This leads to the loss or severe impairment of brain functions that include motor coordination, grip strength, and cognitive and memory abilities. As for MCAo models, the degree of damage to the brain areas will decide the fate of brain functioning (Knowles et al., 2016).

\subsection{Pathophysiology of cerebral ischemia}

The pathophysiological mechanisms that eventually lead to the degeneration of cerebral tissue due to FCI or TGCI seem to be similar (Dirnagl et al., 1999; Leker and Shohami, 2002; Mehta et al., 2007b; Chamorro et al., 2016; Anrather and Iadecola, 2016). They comprise a multitude of pathways, often interconnected and overlapped, that 17) operate at different time points and locations in the extra- and intracellular milieu. The chain of processes begins with the breakdown of ion homeostasis in the neuronal membrane, particularly the failure of the $\mathrm{Na}^{+} / \mathrm{K}^{+}$-adenosine triphosphate pump caused by the energetic collapse. Anoxic depolarization, together with the massive release of glutamate by presynaptic terminals, then occurs. Glutamate stimulates N-methylD-aspartate (NMDA) and $\alpha$-amino-3-hydroxy-5-methyl-4-isoxazole propionic acid (AMPA) receptors. It promotes the continuous influx of $\mathrm{Ca}^{++}$, which in turn activates a series of enzymes and increases oxidative stress in the adjacent postsynaptic cells. These changes occur within minutes and comprise the excitotoxic phase of brain ischemia, with necrotic cell death in the infarcted core. An endogenous protective mechanism against the excess of membrane depolarization that is initiated by reduced energy stores is mediated by the ATP-sensitive $\mathrm{K}^{+}$ channel. Usually closed in normal conditions, this channel is activated rapidly under cerebral ischemic conditions, causing $\mathrm{K}^{+}$efflux, limiting neuronal excitability and $\mathrm{Ca}^{++}$influx, and thus blocking the subsequent neurotoxic biochemical cascade (Liao et al., 2010). Oxidative and nitrosative stress are partly consequences of excitotoxicity and result from an increase in secondary messenger systems coupled to the enzymatic generation of reactive oxygen species (ROS) including superoxide anions, hydrogen peroxide, hydroxyl radicals, and peroxynitrite (Fukuyama et al., 1998). ROS and reactive nitrogen species are shown to act directly as executioners of neuronal cell death during cerebral ischemia (Chan, 2001).

Robust sterile neuroinflammation starts a few hours after the onset of cerebral ischemia and is characterized by blood-brain barrier (BBB) disruption, infiltration of peripheral leukocytes, activation of microglia and astrocytes, and the release of molecules known as damageassociated molecular patterns (DAMPs) by injured and dying cells (Liesz and Kleinschnitz, 2016). Activated immune cells triggered by DAMPs produce inflammatory cytokines, chemokines, and other cytotoxic mediators, leading to exacerbation of cerebral ischemic injury (Gelderblom et al., 2009; Chen and Nuñez, 2010; Yamaguchi et al., 2020). The first immune cell to respond to ischemic injury is brainintrinsic microglia, followed by astrocytes and neutrophils that exacerbate oxidative stress and BBB damage (Justicia et al., 2003). Monocytes, monocyte-derived macrophages, dendritic cells, natural killer cells, and lymphocytes regulate post-ischemic inflammation and may have beneficial or detrimental roles on cerebral injury (Liesz and Kleinschnitz, 2015).

Concomitantly to all neurodegenerative processes, at a particular time point after cerebral ischemia, protective and repair mechanisms such as an increase in the expression of anti-inflammatory mediators and neurotrophic factors and, reactive angiogenesis and neurogenesis take place (Ding et al., 2008; Dirnagl, 2012; Rajkovic et al., 2018). In particular, the cAMP/PKA/pCREB pathway which is closely linked to synaptic plasticity, neurogenesis, and axon growth has been considered a fundamental process that is involved in the recovery of neural function following cerebral ischemic injury (Kitagawa, 2007; Sasaki et al., 2007; Zhao et al., 2015). In vitro and in vivo experiments have demonstrated that the cAMP/PKA/CREB signaling pathway and the downstream CREB effector brain-derived neurotrophic factor (BDNF) can exert neuroprotective effects in ischemic brain injury. CREB expression is upregulated in the brain after MCAo (Salminen et al., 1995), transient global cerebral ischemia (Soares et al., 2016; Mori et al., 2017), and hypoxiaischemic (HI) injury (Zaitseva et al., 2005; Carloni et al., 2010). Intraventricular administration of BDNF attenuated hippocampal damage after global forebrain ischemia (Beck et al., 1994; Wu and Pardridge, 
1999) and reduced infarct size after MCAo (Schäbitz et al., 1997) in rats. Besides, the selective serotonin reuptake inhibitors fluoxetine (Kim et al., 2007) and escitalopram (Lee et al., 2011) protected against neuronal damage after transient global brain ischemia in rats, an effect that was related to the upregulation of BDNF expression. Conversely, a reduction in the BDNF levels in the hippocampus of ischemic mice has been associated with depressive-like behavior induced by cerebral ischemia (Kim et al., 2016; Pang et al., 2015).

\section{Pharmacotherapy for cerebral ischemia}

The primary purpose of neuroprotective pharmacotherapy is to reduce the severity of initial damage and improve functional outcome weeks and months after a cerebral ischemic event. However, advances in pharmacotherapy to cerebral ischemia have been limited. The thrombolytic agent recombinant tissue plasminogen activator (rtPA) is the only FDA-approved therapy for stroke. However, the narrow time window of treatment (within $4.5 \mathrm{~h}$ of the ischemic event) and the possible occurrence of hemorrhage limits its applicability to a minority of patients (National Institute of Neurological Disorders and Stroke rt-PA Stroke Study Group, 1995). Moreover, reperfusion itself is associated with further neuronal damage by activation neuroinflammatory response, thus causing tissue injury (Dhir et al., 2020). Antiplatelet drugs, anticoagulants, and statins act as prophylactics and have no immediate effect following an acute ischemic attack (Tajiri et al., 2013). Therefore, there is a substantial need for neuroprotective strategies to prevent neuronal damage and promote functional recovery after cerebral ischemia.

\section{Experimental evidence and putative mechanisms underlying the neuroprotective effects of $5-\mathrm{HT}_{1 \mathrm{~A}}$ receptor agonists in experimental cerebral ischemia}

\section{1. $5-H T_{1 A}$ agonists and MCAo models}

Studies on the involvement of the $5-\mathrm{HT}_{1 \mathrm{~A}}$ receptor in cerebral ischemia advanced from the 1990s onwards after the development of selective $5-\mathrm{HT}_{1 \mathrm{~A}}$ receptor agonists. Bielenberg and Burkhardt (1990) have shown the effects of acute treatment with various $5-\mathrm{HT}_{1 \mathrm{~A}}$ receptor agonists, including the full agonists 8-OH-DPAT and BayR 1531, or partial agonists as buspirone, gepirone, and ipsapirone, in mice and rats subjected to permanent MCAo (Table 2). In general, the drugs administered $30 \mathrm{~min}$ before or $60 \mathrm{~min}$ after MCAo and caused a significant reduction in the infarct volume in the cerebral cortex. Ipsapirone and Bay R 1531 reduced cortical infarct size by more than $60 \%$ as compared to controls.

Neuroprotective effects have also been shown with partial agonists including CM 57943, urapidil, S1467,1 and ipsapirone in rodents subjected to MCAo (Prehn et al., 1991, 1993; Kamei et al., 2001; Johansen et al., 2014). Both 5-HT 1 A agonists CM 57943 and urapidil promoted a decrease in the size of infarct in the cerebral cortex of ischemic rodents (Table 2). Moreover, these 5- $\mathrm{HT}_{1 \mathrm{~A}}$ agonists were able to reduce neuronal damage of cultured neocortical and hippocampal neurons subjected to chemical hypoxia or glutamate overload in a dose-dependent manner (Prehn et al., 1993). Similarly, the potent 5- $\mathrm{HT}_{1 \mathrm{~A}}$ agonist, compound 26 (2-\{6-[(3,4-dihydro-2chromeen-2-ylmethyl)amino]hexyl\}tetrahydro-

$1 \mathrm{H}$-pyrrolo[1,2c] imidazole-1,3(2H)-dione), has produced neuroprotective effects in both in vitro assays using primary cell cultures from rat hippocampus as well as in rats with MCAo (Table 1) (Marco et al., 2011). Repinotan was also effective in decreasing the infarct size when administered $4 \mathrm{~h}$ after MCAo (Semkova et al., 1998; Mauler and Horváth, 2005).

In another study, Kamei et al. (2001) have demonstrated the neuroprotective effects of buspirone and compound 5 (SUN N 4057) in rats subjected to MCAo. In this study, the measurement of peripheral type benzodiazepine binding sites (PTBBS) in ipsilateral cortical and striatal homogenates was carried out as an index for quantification of neuronal damage 10 days after cerebral ischemia. A single administration of compound 5 exerted a dose-dependent reduction of PTBBS levels and reduced the ischemic hyperthermia at neuroprotective doses.

Extensive preclinical studies have been done with the full $5-\mathrm{HT}_{1 \mathrm{~A}}$ receptor agonist, repinotan (Bay X 3702) after permanent (Semkova et al., 1998) or transient (Mauler and Horváth, 2005; Kukley et al., 2001) MCAo. Repinotan, when administered immediately after reperfusion or even $5 \mathrm{~h}$ later, reduced the cortical infarction volume up to $97 \%$ in rats with MCAo. In vitro, the activity of repinotan was abolished by WAY 100635 , indicating that the effect was mediated via $5-\mathrm{HT}_{1 \mathrm{~A}}$ receptor stimulation. Also, repinotan elevated the level of the apoptosisinhibiting protein BCL-2 in the ipsilateral cerebral cortex of ischemic animals, indicating a neuroprotective effect of repinotan treatment (Kukley et al., 2001).

The favorable neuroprotective efficacy, broad dose-response curve, and prolonged therapeutic window observed in those stroke models positioned repinotan as a promising candidate for clinical trials for treating acute ischemic stroke in humans (Berends et al., 2005). The tolerability, safety, and dose of repinotan were investigated in Phase II double-blind, placebo-controlled study in which 240 patients with acute hemispheric ischemia (focal ischemia) received placebo or repinotan at $0.5,1.25$ or $2.5 \mathrm{mg} / \mathrm{kg}$ given by i.v. infusion during $72 \mathrm{~h}$. Treatment was started within $6 \mathrm{~h}$ of symptoms onset and evaluations were performed at one and 3 months later. Although both doses of $0.5 \mathrm{mg} / \mathrm{kg} /$ day and 1.25 $\mathrm{mg} / \mathrm{kg} /$ day were well tolerated with few patients requiring discontinuation, a higher incidence of serotonergic adverse side effects including shivering, heavy sweating, restlessness, agitation and confusion was detected in the $2.5 \mathrm{mg} / \mathrm{kg} /$ day dosage group (Teal et al., 2005). To optimize repinotan exposure of patients with stroke, a Randomized Exposure Controlled Trial (RECT) was design for a Phase IIB study with repinotan (Teal et al., 2009). Several changes were implemented after the randomization of 98 patients into RECT and included: i) reduction of the allowed treatment time window from 6 to $4.5 \mathrm{~h}$ to increase the potential for neuroprotective effect; ii) a loading dose to reach target plasma concentrations sooner; and iii) patient assignment in a 1:1 ratio to treatment with repinotan or placebo (changed from 2:1 in RECT). However, this study failed to demonstrate a clinical benefit of repinotan and the development of repinotan in ischemic stroke was discontinued (Teal et al., 2009).

Finally, other preclinical results have supported the direct involvement of $5-\mathrm{HT}_{1 \mathrm{~A}}$ receptors in neuroprotective therapies for cerebral ischemia. In this respect, cannabidiol, which is the second most abundant Cannabis sativa derived cannabinoid, reduced the infarct volume and increased the CBF in mice with MCAo. The effect of cannabidiol was inhibited by the $5-\mathrm{HT}_{1 \mathrm{~A}}$ antagonist, WAY100635, but not by a CB1 receptor antagonist or by a vanilloid receptor antagonist (Mishima et al., 2005).

\section{2. $5-H T_{1 A}$ receptor agonists and TGCI models}

Transient global cerebral ischemia is characterized by an abrupt and complete reduction of blood flow and glucose, which causes selective neuronal injury to vulnerable brain areas such as the hippocampus. As shown in Table 2, single administration of CM 57943, urapidil, repinotan, ipsapirone and repinotan (BAY R 1531), 15 to $30 \mathrm{~min}$ before or immediately after 2-VO resulted in a reduction of neuronal loss in the CA1 hippocampal subarea and entorhinal cortex of rats (Prehn et al., 1991, 1993; Schaper et al., 2000). The anti-apoptotic effect of repinotan was abolished by cotreatment with the $5-\mathrm{HT}_{1 \mathrm{~A}}$ receptor antagonist WAY100635 (Schaper et al., 2000). A 7-day infusion with the 5- $\mathrm{HT}_{1 \mathrm{~A}}$ agonist, 8-OH-DPAT, prevented the neuronal loss in the hippocampal CA1 subarea induced by 2 -VO in rats. Hypothermia was proposed as a possible explanation for the neuroprotective effect of 8-OH-DPAT (Torup et al., 2000).

Mongolian gerbils have unique vascular anatomy with no posterior 
Table 2

$5-\mathrm{HT}_{1 \mathrm{~A}}$ receptor agonists and animal models of cerebral ischemia

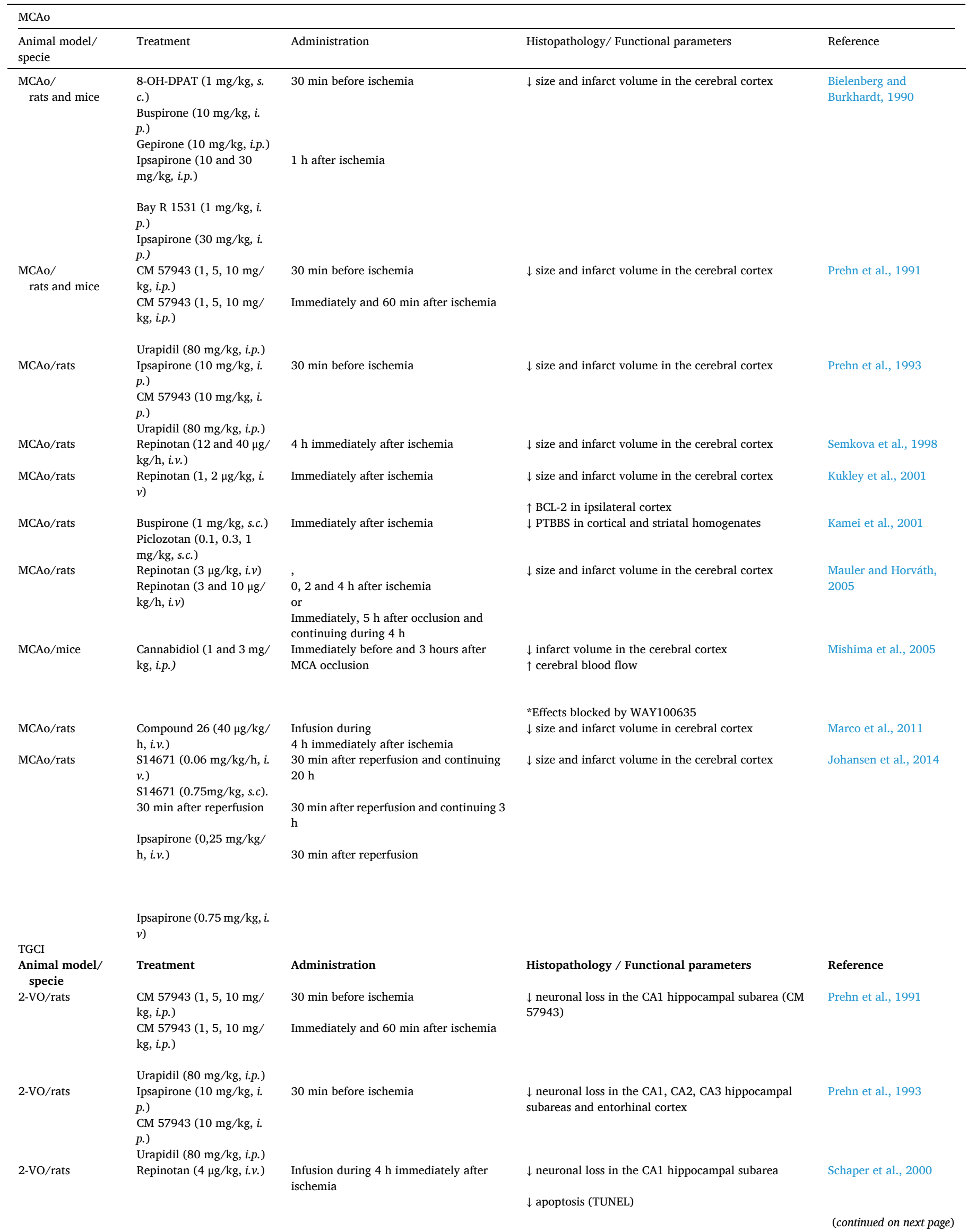


Table 2 (continued)

\begin{tabular}{|c|c|c|c|c|}
\hline MCAo & & & & \\
\hline $\begin{array}{l}\text { Animal model/ } \\
\text { specie }\end{array}$ & Treatment & Administration & Histopathology/ Functional parameters & Reference \\
\hline 2 -VO/rats & $\begin{array}{l}\text { 8-OH-DPAT }(125 \mu \mathrm{g} / \mathrm{kg} / \\
\text { h, i.v. }\end{array}$ & $\begin{array}{l}\text { Infusion during } 7 \text { days immediately after } \\
\text { ischemia }\end{array}$ & $\begin{array}{l}\text { *Effects abolished by WAY100635 } \\
\downarrow \text { neuronal loss in the CA1 hippocampal subarea }\end{array}$ & Torup et al., 2000 \\
\hline $\begin{array}{l}\text { BCCAO/ } \\
\text { Mongolian } \\
\text { gerbil }\end{array}$ & $\begin{array}{l}\text { Ipsapirone ( } 3 \mathrm{mg} / \mathrm{kg}, i . p .) \\
\text { Bay R } 1531 \text { ( } 3 \mathrm{mg} / \mathrm{kg}, i \text {. } \\
\text { p.) }\end{array}$ & $\begin{array}{l}15 \text { min before followed by } 2 x / \text { day during } \\
3 \text { days }\end{array}$ & $\downarrow$ neuronal loss in the CA1 hippocampal subarea & Bode-Greuel et al., 1990 \\
\hline $\begin{array}{l}\text { BCCAO/ } \\
\text { Mongolian } \\
\text { gerbil }\end{array}$ & $\begin{array}{l}\text { 8-OH-DPAT ( } 1 \text { and } 3 \mathrm{mg} \text { / } \\
\text { kg, i.p.) } \\
\text { Buspirone ( } 3 \text { and } 10 \mathrm{mg} \text { / } \\
\text { kg, i.p.) } \\
\text { Flesinoxan ( } 1 \text { and } 3 \mathrm{mg} / \\
\text { kg, i.p.) }\end{array}$ & $\begin{array}{l}15 \text { min before ischemia, followed by } 2 x / \\
\text { day during } 3 \text { days }\end{array}$ & $\begin{array}{l}\downarrow \text { neuronal loss in the CA1 hippocampal subarea } \\
\text { (8-OH-DPAT) } \\
\downarrow \text { hyperlocomotion induced by BCCAO }\end{array}$ & Piera et al., 1995 \\
\hline $\begin{array}{l}\text { BCCAO/ } \\
\text { Mongolian } \\
\text { gerbil }\end{array}$ & $\begin{array}{l}\text { 8-OH-DPAT }(1 \mathrm{mg} / \mathrm{kg}, s \text {. } \\
\text { c.) }\end{array}$ & $30 \mathrm{~min}$ before ischemia & $\begin{array}{l}\downarrow \text { neuronal loss in CA1 hippocampal subarea } \\
\uparrow \text { BDNF levels in the CA1 hippocampal subregion } \\
\downarrow \text { NR1receptor subunit expression }\end{array}$ & $\begin{array}{l}\text { Salazar-Colocho et al., } \\
2007,2008\end{array}$ \\
\hline $\begin{array}{l}\text { BCCAO/ } \\
\text { mice }\end{array}$ & $\begin{array}{l}\text { NLX-101(0.32 mg/kg, } i . \\
\text { p.) }\end{array}$ & $\begin{array}{l}\text { Once a day } 1 \text { week before and during } 21 \\
\text { days after ischemia }\end{array}$ & $\begin{array}{l}\downarrow \text { memory deficits and } \downarrow \text { despair-like behaviors } \\
\uparrow \text { BDNF in the hippocampus and PFC } \\
\uparrow \text { PSD-95 and } \uparrow \text { synaptophysin in the hippocampus } \\
(+) \text { Dendritic remodeling in the hippocampus and PFC }\end{array}$ & Aguiar et al., 2020 \\
\hline
\end{tabular}

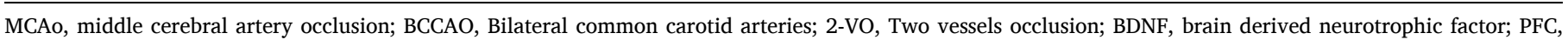
prefrontal cortex; PTBBS, peripheral type benzodiazepine binding sites; PSD-95, postsynaptic density protein; $\uparrow$, increase; $\downarrow$, decrease; (+), positive effect.

communicating artery, which connects the carotid and vertebrobasilar arterial system. Thus, BCCAO in gerbils results in severe neurological signs and death of hippocampal CA1 neurons (Traystman, 2003). Neuroprotective effects have been detected in gerbils subjected to BCCAO and treated with $5-\mathrm{HT}_{1 \mathrm{~A}}$ receptor agonists (Table 2). Ipsapirone, and Bay $\mathrm{R} 1531$ attenuated neuronal loss in the hippocampal CA1 region in gerbils subjected to BCCAO (Bode-Greuel et al., 1990; Salazar-Colocho et al., 2007, 2008). Bay R1531 showed a powerful neuroprotective effect with $100 \%$ preservation of neurons while gepirone and 8-OH-DPAT were ineffective. Besides, Piera et al. (1995) have observed that 8-OHDPAT, buspirone, and flesinoxan abolished the hyperactivity induced by BCCAO in gerbils. However, the authors found no correlation between the behavioral effects of those $5-\mathrm{HT}_{1 \mathrm{~A}}$ agonists and the extent of their reduction in neuronal damage: only 8-OH-DPAT reduced neuronal degeneration induced by cerebral ischemia. It was suggested that the ineffectiveness of buspirone and flesinoxan may have been related to the partial agonist activity of those compounds at the $5-\mathrm{HT}_{1 \mathrm{~A}}$ receptor.

Salazar-Colocho et al. $(2007,2008)$ demonstrated that pretreatment with 8-OH-DPAT increased BDNF levels and prevented the neuronal loss in the hippocampal CA1 region of gerbils with BCCAo. Also, pretreatment with 8-OH-DPAT decreased phosphorylation of NMDA receptors in the hippocampus of ischemic gerbils, attenuating neurotoxicity and neuronal loss (Tingley et al., 1997). The authors concluded that NR1 phosphorylation and BDNF accounted, at least in part, for the neuroprotective effects of pretreatment with 8-OH-DPAT.

\section{New perspectives for targeting $5-\mathrm{HT}_{1 \mathrm{~A}}$ receptors: 'biased' receptor agonists differentiating between receptor subpopulations}

The studies described above and listed in Table 2 provide a clear demonstration that parameters associated with cerebral ischemia, can be reduced via activation of $5-\mathrm{HT}_{1 \mathrm{~A}}$ receptors. Overall, $5-\mathrm{HT}_{1 \mathrm{~A}}$ receptor agonists reduced the size and infarct volume in the cerebral cortex of rodents subjected to MCAo and prevented hippocampal neuronal loss in the hippocampus of rodents with global cerebral ischemia. Such studies buttress the rationale for pursuing investigation of this class of compounds and suggest that they could lead to promising pharmacotherapeutics. Nevertheless, the clinical benefits for ischemia patients are currently far from impressive. The only commercialized drug in Table 2 is buspirone, which is commonly used as an anxiolytic though it has attracted little (if any) attention as a clinical anti-ischemia treatment. Interestingly it has been used as an anti-shivering treatment during the intervention by cooling body temperature because if left uncontrolled, shivering can defeat the cooling process and eliminate the potential benefits of therapeutic intervention in brain ischemia, see EuroHYP-1 and ICTuS $2 / 3$ trials on clinicaltrials.gov. Some of the other compounds, including ipsapirone and gepirone, are close clinical analogs of buspirone and possess similar pharmacological profiles, i.e., partial agonist properties at $5-\mathrm{HT}_{1 \mathrm{~A}}$ receptors and some limited selectivity over multiple other cross-reacting sites, including dopaminergic and adrenergic receptors. Similar limitations also apply to urapidil and piclozotan although not to repinotan, which is potent and selective for $5-\mathrm{HT}_{1 \mathrm{~A}}$ receptors. As surmised by Piera et al. (1995), the limited neuroprotective effects of at least some of the tested compounds may also be actually due to their insufficient agonist efficacy at $5-\mathrm{HT}_{1 \mathrm{~A}}$ receptors. Thus, modestefficacy partial receptor agonism may be insufficient to elicit an optimal therapeutic benefit.

Another important point to consider is that the tested compounds interact broadly with $5-\mathrm{HT}_{1 \mathrm{~A}}$ receptor subpopulations throughout the brain, irrespective of neuronal or regional localization. This lack in receptor discrimination may be a limiting factor in the anti-ischemic efficacy of the agonists because $5-\mathrm{HT}_{1 \mathrm{~A}}$ receptors in different brain regions can mediate diverging or even contradictory responses. For example, activation of $5-\mathrm{HT}_{1 \mathrm{~A}}$ autoreceptors in the raphe inhibits serotonergic tone and dampens 5-HT release throughout terminal regions, thus indirectly opposing activation of postsynaptic $5-\mathrm{HT}_{1 \mathrm{~A}}$ receptors (Fig. 2). Moreover, as described above, the preferential targeting by biased agonists of raphe-located $5-\mathrm{HT}_{1 \mathrm{~A}}$ autoreceptors or post-synaptic heteroreceptors is not due to differences in the receptor protein itself or binding affinity per se. The distinct responses to the biased $5-\mathrm{HT}_{1 \mathrm{~A}}$ agonists have been attributable to regional coupling differences of the 5- 
$\mathrm{HT}_{1 \mathrm{~A}}$ receptors to certain G-protein subtypes, regulators of G-protein signaling, or transcriptional regulation (Newman-Tancredi, 2011). There are distinct regional intracellular signaling responses to postsynaptic $5-\mathrm{HT}_{1 \mathrm{~A}}$ receptor activation: ERK1/2 signaling, which is important for neuroprotective activity, varies in different brain regions (vide supra) and is known to be stimulated by $5-\mathrm{HT}_{1 \mathrm{~A}}$ receptors in the cortex and hippocampus.

Taken together, these considerations suggest that improved treatment of ischemia may require $5-\mathrm{HT}_{1 \mathrm{~A}}$ receptor agonists that fulfill 3 conditions: (i) high receptor selectivity, (ii) efficacious receptor activation (full agonism), and (iii) functional selectivity for ERK1/2 activation in vulnerable brain regions expressing postsynaptic $5-\mathrm{HT}_{1 \mathrm{~A}}$ heteroreceptors. These criteria have not previously been met by classical 5$\mathrm{HT}_{1 \mathrm{~A}}$ receptor agonists but a new generation of compounds has become available that discriminate between receptor subpopulations in specific brain regions (Sniecikowska et al., 2019). An extensive series of in vitro, ex vivo, electrophysiological, neurochemical, behavioral, and brain imaging studies have shown that these 'biased agonists' differentially target $5-\mathrm{HT}_{1 \mathrm{~A}}$ autoreceptors or postsynaptic $5-\mathrm{HT}_{1 \mathrm{~A}}$ heteroreceptors in different brain regions (Newman-Tancredi, 2011). The prototypical postsynaptic $5-\mathrm{HT}_{1 \mathrm{~A}}$ receptor biased agonist is NLX-101 (also known as F15599), a compound that preferentially and potently activates ERK1/2 phosphorylation and elicits cortical pyramidal neuron electrical activity without inhibiting serotonin neuron firing (Newman-Tancredi et al., 2009; Lladó-Pelfort et al., 2010). NLX-101 is undergoing early clinical development for breathing difficulties in Rett's syndrome and as a potential rapid-acting antidepressant. Indeed, NLX-101 exhibits procognitive and antidepressant activity in a variety of animal models (Depoortère et al., 2010; van Goethem et al., 2015; Depoortère et al., 2019). Notably, a recent study by Aguiar et al. (2020) showed that chronic treatment with NLX-101 attenuated cognitive impairments and despair-like behaviors induced by BCCAO in mice. Also, NLX-101 blocked the increase in plasma corticosterone levels and restored BDNF, synaptophysin, and PSD-95 protein levels in the hippocampus of mice subjected to BCCAO. These findings are significant because they suggest that preferential targeting of postsynaptic $5-\mathrm{HT}_{1 \mathrm{~A}}$ receptors may be able to rescue the neurostructural damage induced by BCCAO as well as its functional deficits on mood and cognitive function. If these findings can be translated into a clinical setting, they could provide a novel basis for the development of 'biased' $5-\mathrm{HT}_{1 \mathrm{~A}}$ heteroreceptor agonists in the treatment of ischemia.

\section{General considerations and conclusions}

The primary purpose of neuroprotective pharmacotherapy is to reduce the severity of initial damage and improve functional outcomes in the weeks and months after a cerebral ischemic event. In this review, we presented experimental evidence that $5-\mathrm{HT}_{1 \mathrm{~A}}$ receptor agonists were able to prevent the neuronal damage induced by transient focal or global cerebral ischemia. Indeed, over several decades abundant evidence has been provided that $5-\mathrm{HT}_{1 \mathrm{~A}}$ receptors are involved in several processes that may attenuate cerebral ischemic injury at varying time points. Agonist activation of $5-\mathrm{HT}_{1 \mathrm{~A}}$ receptors can promote hyperpolarization due to an increase in the inwardly rectifying potassium current and inhibit ischemia-induced excessive damage due to glutamate release. Besides, $5-\mathrm{HT}_{1 \mathrm{~A}}$ receptor agonists have been reported to exert neuroprotective effects by promoting hypothermia. Finally, $5-\mathrm{HT}_{1 \mathrm{~A}}$ receptor agonists have been involved in the neuroplastic changes in the hippocampus, including an increase in BDNF and neurogenesis which are reduced after a cerebral ischemic event.

Nevertheless, despite these compelling findings, little progress has been made in translating them into a clinical application. Most of the preclinical studies have focused on acute or short-term treatments, i.e., before, immediately after, or during 3 to 7 days after cerebral ischemia (Table 2), to promote neuronal survival. The main measurement (outcome) was the histological damage in vulnerable areas (cortical infarct size for MCAo and hippocampal cell loss for TGCI). However, the promotion of neuronal survival is of little therapeutic utility unless followed by successful brain remodeling and plasticity - which is which $5-\mathrm{HT}_{1 \mathrm{~A}}$ receptor agonists produce neuroprotection need more clarification and systematic studies. Only two studies confirmed direct 5- $\mathrm{HT}_{1 \mathrm{~A}}$ receptor involvement by showing that the neuroprotective effect of 5$\mathrm{HT}_{1 \mathrm{~A}}$ receptor agonists was blocked by a $5-\mathrm{HT}_{1 \mathrm{~A}}$ receptor antagonist, WAY100635 (Schaper et al., 2000; Mishima et al., 2005). Restoring functional deficits in ischemic patients is critical for improvements in the patient's quality of life and is, therefore, an important measure of a treatment's therapeutic potential in animal models (Liao et al., 2008; Veerbeek et al., 2011). To our knowledge, only two studies measured functional recovery with a $5-\mathrm{HT}_{1 \mathrm{~A}}$ receptor agonist after cerebral ischemia (Piera et al., 1995; Aguiar et al., 2020). Interestingly, one of those studies indicates that the postsynaptic $5-\mathrm{HT}_{1 \mathrm{~A}}$ heteroreceptor is involved in both neuroprotection and functional recovery, drawing attention to a possible novel and promising strategy for improved therapeutic intervention. A bias for postsynaptic receptors is important as excessive and indistinct activation of both pre- and postsynaptic 5$\mathrm{HT}_{1 \mathrm{~A}}$ receptors may induce a broad range of physiological effects related to the expression of these receptors in different brain regions. Hence, as well as the desired neuroprotective properties, $5-\mathrm{HT}_{1 \mathrm{~A}}$ receptor activation can elicit autonomic, neuroendocrine, neuropsychiatric, and hypothermic effects, depending on the brain regions involved. In this context, it is important to note that the classical 5- $\mathrm{HT}_{1 \mathrm{~A}}$ receptor agonists activate indiscriminately both $5-\mathrm{HT}_{1 \mathrm{~A}}$ autoreceptors, which induce an inhibitory effect on serotonergic tone, and postsynaptic heteroreceptors, which are associated with inducing a positive effect on neuroprotective mechanisms. Such lack of functional selectivity may result in a limited net beneficial effect of such agonists, possibly dampening therapeutic efficacy and thus reducing their clinical applications. The development of a biased $5-\mathrm{HT}_{1 \mathrm{~A}}$ receptor agonist targeting postsynaptic heteroreceptors might overcome such limitations and represent an attractive therapeutic strategy to provide neuroprotection in ischemic cerebral conditions.

\section{Declaration of Competing Interest}

The author(s) declared no potential conflicts of interest with respect to the research, authorship, and/or publication of this article: AN-T is employee and/or stockholder of Neurolixis, Inc. RPA, JP and RMWO declare that there is no conflict of interest.

\section{Acknowledgements}

The authors gratefully acknowledge the financial support by the Coordenação de Aperfeiçoamento de Pessoal de Nível Superior (CAPES, Program CAPES/NUFFIC 8888.7156.527/2017-00), Conselho Nacional de Desenvolvimento Científico e Tecnológico (CNPq), State University of Maringá and the University of Maastricht.

\section{References}

Adayev, T., El-Sherif, Y., Barua, M., Penington, N.J., Banerjee, P., 1999. Agonist stimulation of the serotonin1A receptor causes suppression of anoxia-induced apoptosis via mitogen-activated protein kinase in neuronal HN2-5 cells. J Neurochem. 72 (4), 1489-1496. https://doi.org/10.1046/j.14714159.1999.721489.x.

Aguiar, R.P., Soares, L.M., Meyer, E., et al., 2020. Activation of $5-\mathrm{HT}_{1 \mathrm{~A}}$ postsynaptic receptors by NLX-101 results in functional recovery and an increase in neuroplasticity in mice with brain ischemia. Prog Neuropsychopharmacol Biol Psychiatry. 99, 109832. https://doi.org/10.1016/j.pnpbp.2019.109832.

Albert, P.R., Vahid-Ansari, F., 2019. The 5-HT1A receptor: Signaling to behavior. Biochimie. 161, 34-45. https://doi.org/10.1016/j.biochi.2018.10.015.

Albert, P.R., Zhou, Q.Y., Van Tol, H.H., Bunzow, J.R., Civelli, O., 1990. Cloning, functional expression, and mRNA tissue distribution of the rat 5-hydroxytryptamine1A receptor gene. J Biol Chem. 265 (10), 5825-5832.

Anderson, C.A., Arciniegas, D.B., 2010. Cognitive sequelae of hypoxic-ischemic brain injury: a review. NeuroRehabilitation. 26 (1), 47-63. https://doi.org/10.3233/NRE2010-0535. 
Anrather, J., Iadecola, C., 2016. Inflammation and stroke: an overview. Neurotherapeutics. 13 (4), 661-670. https://doi.org/10.1007/s13311-016-0483-x.

Ayerbe, L., Ayis, S., Wolfe, C.D., Rudd, A.G., 2013. Natural history, predictors and outcomes of depression after stroke: systematic review and meta-analysis. Br J Psychiatry. 202 (1), 14-21. https://doi.org/10.1192/bjp.bp.111.107664.

Bang, S.J., Jensen, P., Dymecki, S.M., Commons, K.G., 2012. Projections and interconnections of genetically defined serotonin neurons in mice. Eur J Neurosci. 35 (1), 85-96. https://doi.org/10.1111/j.1460-9568.2011.07936.x.

Bardutzky, J., Shen, Q., Henninger, N., Bouley, J., Duong, T.Q., Fisher, M., 2005. Differences in ischemic lesion evolution in different rat strains using diffusion and perfusion imaging. Stroke. 36 (9), 2000-2005. https://doi.org/10.1161/01. STR.0000177486.85508.4d.

Beck, T., Lindholm, D., Castrén, E., Wree, A., 1994. Brain-derived neurotrophic factor protects against ischemic cell damage in rat hippocampus. J Cereb Blood Flow Metab. 14 (4), 689-692. https://doi.org/10.1038/jcbfm.1994.86.

Benjamin, E.J., Virani, S.S., Callaway, C.W., et al., 2018. American Heart Association Council on Epidemiology and Prevention Statistics Committee and Stroke Statistics Subcommittee. Heart Disease and Stroke Statistics-2018 Update: A Report From the American Heart Association. Circulation. 137 (12), e67-e492. https://doi.org/ 10.1161/CIR.0000000000000558.

Berends, A.C., Luiten, P.G., Nyakas, C., 2005. A review of the neuroprotective properties of the 5-HT1A receptor agonist repinotan $\mathrm{HCl}$ (BAYx3702) in ischemic stroke. CNS Drug Rev. 11 (4), 379-402. https://doi.org/10.1111/j.1527-3458.2005.tb00055.x.

Bielenberg, G.W., Burkhardt, M., 1990. 5-hydroxytryptamine1A agonists. A new therapeutic principle for stroke treatment. Stroke. 21 (12 Suppl), IV161-IV163.

Blendy, J.A., 2006. The role of CREB in depression and antidepressant treatment. Biol Psychiatry. 59 (12), 1144-1150. https://doi.org/10.1016/j.biopsych.2005.11.003.

Bockaert, J., Claeysen, S., Compan, V., Dumuis, A., 2004. 5-HT4 receptors. Curr Drug Targets CNS Neurol Disord. 3 (1), 39-51. https://doi.org/10.2174/ 1568007043482615.

Bockaert, J., Claeysen, S., Dumuis, A., Marin, P., 2010. Classification and Signaling Characteristics of 5-HT Receptors. Christian P. Müller; Barry L. Jacobs. Handbook of the Behavioral Neurobiology of Serotonin, 21, Elsevier, pp.103-121, Handbook of Behavioral Neuroscience, 978-0-12-374634-4.

Bode-Greuel, K.M., Klisch, J., Horváth, E., Glaser, T., Traber, J., 1990. Effects of 5 hydroxytryptamine1A-receptor agonists on hippocampal damage after transient forebrain ischemia in the Mongolian gerbil. Stroke. 21 (12 Suppl), IV164-IV166.

Bruns, D., Riedel, D., Klingauf, J., Jahn, R., 2000. Quantal release of serotonin. Neuron 28 (1), 205-220 s0896-6273(00)00097-0.

Bunin, M.A., Wightman, R.M., 1999. Paracrine neurotransmission in the CNS: involvement of 5-HT. Trends Neurosci. 22 (9), 377-382. https://doi.org/10.1016/ s0166-2236(99)01410-1.

Carlezon Jr., W.A., Duman, R.S., Nestler, E.J., 2005. The many faces of CREB. Trends Neurosci. 28 (8), 436-445. https://doi.org/10.1016/j.tins.2005.06.005.

Carloni, S., Girelli, S., Scopa, C., Buonocore, G., Longini, M., Balduini, W., 2010. Activation of autophagy and Akt/CREB signaling play an equivalent role in the neuroprotective effect of rapamycin in neonatal hypoxia-ischemia. Autophagy. 6 (3), 366-377. https://doi.org/10.4161/auto.6.3.11261.

Cassel, J.C., Jeltsch, H., 1995. Serotoninergic modulation of cholinergic func-tion in the central nervous system: cognitive implications. Neuroscience. 69 (1), 1-41.

Celada, P., Puig, M.V., Artigas, F., 2013. Serotonin modulation of cortical neurons and networks. Front Integr Neurosci. 7, 25. https://doi.org/10.3389/fnint.2013.00025.

Chameau, P., van Hooft, J.A., 2006. Serotonin 5-HT(3) receptors in the central nervous system. Cell Tissue Res. 326 (2), 573-581. https://doi.org/10.1007/s00441-0060255-8.

Chamorro, Á., Dirnagl, U., Urra, X., Planas, A.M., 2016. Neuroprotection in acute stroke: targeting excitotoxicity, oxidative and nitrosative stress, and inflammation. Lancet Neurol. 15 (8), 869-881. https://doi.org/10.1016/S1474-4422(16)00114-9.

Chan, P.H., 2001. Reactive oxygen radicals in signaling and damage in the ischemic brain. J Cereb Blood Flow Metab. 21 (1), 2-14. https://doi.org/10.1097/00004647 200101000-00002.

Chen, G.Y., Nuñez, G., 2010. Sterile inflammation: sensing and reacting to damage. Nat Rev Immunol. 10 (12), 826-837. https://doi.org/10.1038/nri2873.

Chilmonczyk, Z., Bojarski, A.J., Pilc, A., Sylte, I., 2015. Functional Selectivity and Antidepressant Activity of Serotonin 1A Receptor Ligands. Int J Mol Sci. 16 (8), 18474-18506. https://doi.org/10.3390/ijms160818474.

Codony, X., Burgueño, J., Ramírez, M.J., Vela, J.M., 2010. 5-HT6 receptor signal transduction second messenger systems. Int Rev Neurobiol. 94, 89-110. https://doi. org/10.1016/B978-0-12-384976-2.00004-6.

Colgan, L.A., Putzier, I., Levitan, E.S., 2009. Activity-dependent vesicular monoamine transporter-mediated depletion of the nucleus supports somatic release by serotonin neurons. J Neurosci. 29 (50), 15878-15887. https://doi.org/10.1523/ JNEUROSCI.4210-09.2009.

Colgan, L.A., Cavolo, S.L., Commons, K.G., Levitan, E.S., 2012. Action potentialindependent and pharmacologically unique vesicular serotonin release from dendrites. J Neurosci. 32 (45), 15737-15746. https://doi.org/10.1523/ JNEUROSCI.0020-12.2012.

Courtney, N.A., Ford, C.P., 2016. Mechanisms of 5-HT1A receptor-mediated transmission in dorsal raphe serotonin neurons. J Physiol. 594 (4), 953-965. https://doi.org/ 10.1113/JP271716.

Cowen, D.S., Johnson-Farley, N.N., Travkina, T., 2005. 5-HT receptors couple to activation of Akt, but not extracellular-regulated kinase (ERK), in cultured hippocampal neurons. J Neurochem. 93 (4), 910-917. https://doi.org/10.1111/ j.1471-4159.2005.03107.x.
David, D.J., Gardier, A.M., 2016. The pharmacological basis of the serotonin system: Application to antidepressant response. Encephale. 42 (3), 255-263. https://doi. org/10.1016/j.encep.2016.03.012.

De Kock, C.P., Cornelisse, L.N., Burnashev, N., et al., 2006. NMDA receptors trigger neurosecretion of 5-HT within dorsal raphe nucleus of the rat in the absence of action potential firing. J Physiol. 577 (Pt 3), 891-905. https://doi.org/10.1113/ jphysiol.2006.115311.

De Vivo, M., Maayani, S., 1986. Characterization of the 5-hydroxytryptamine1a receptormediated inhibition of forskolin-stimulated adenylate cyclase activity in guinea pig and rat hippocampal membranes. J Pharmacol Exp Ther. 238 (1), 248-253.

Debata, P.R., Ranasinghe, B., Berliner, A., Curcio, G.M., Tantry, S.J., Ponimaskin, E., Banerjee, P., 2010. Erk1/2-dependent phosphorylation of PKCalpha at threonine 638 in hippocampal 5-HT(1A) receptor-mediated signaling. Biochem Biophys Res Commun. 397 (3), 401-406. https://doi.org/10.1016/j.bbrc.2010.05.096.

Delavaran, H., Jönsson, A.C., Lövkvist, H., Iwarsson, S., Elmståhl, S., Norrving, B., Lindgren, A., 2017. Cognitive function in stroke survivors: A 10-year follow-up study. Acta Neurol Scand. 136 (3), 187-194. https://doi.org/10.1111/ane.12709.

Della Rocca, G.J., Mukhin, Y.V., Garnovskaya, M.N., et al., 1999. Serotonin 5-HT1A receptor-mediated Erk activation requires calcium/calmodulin-dependent receptor endocytosis. J Biol Chem. 274 (8), 4749-4753. https://doi.org/10.1074/ jbc. 274.8.4749.

Depoortère, R., Auclair, A.L., Bardin, L., Colpaert, F.C., Vacher, B., Newman-Tancredi, A., 2010. F15599, a preferential post-synaptic 5-HT1A receptor agonist: activity in models of cognition in comparison with reference 5-HT1A receptor agonists. Eur Neuropsychopharmacol. 20 (9), 641-654. https://doi.org/10.1016/j. euroneuro.2010.04.005.

Depoortère, R., Papp, M., Gruca, P., et al., 2019. Cortical 5-hydroxytryptamine 1A receptor biased agonist, NLX-101, displays rapid-acting antidepressant-like properties in the rat chronic mild stress model. J Psychopharmacol. 33 (11), 1456-1466. https://doi.org/10.1177/0269881119860666.

Dhir, N., Medhi, B., Prakash, A., Goyal, M.K., Modi, M., Mohindra, S., 2020. 2020. Preclinical to clinical translational failures and current status of clinical trials in stroke therapy: A brief review. Curr Neuropharmacol 18 (7), 596-612. https://doi.org/ 10.2174/1570159X18666200114160844.

Ding, G., Jiang, Q., Li, L., et al., 2008. Angiogenesis detected after embolic stroke in rat brain using magnetic resonance T2*WI. Stroke. 39 (5), 1563-1568. https://doi.org/ 10.1161/STROKEAHA.107.502146.

Dirnagl, U., 2012. Pathobiology of injury after stroke: the neurovascular unit and beyond. Ann N Y Acad Sci. 1268, 21-25. https://doi.org/10.1111/j.1749 6632.2012.06691.x.

Dirnagl, U., Endres, M., 2014. Found in translation: preclinical stroke research predicts human pathophysiology, clinical phenotypes, and therapeutic outcomes. Stroke. 45 (5), 1510-1518. https://doi.org/10.1161/STROKEAHA.113.004075.

Dirnagl, U., Iadecola, C., Moskowitz, M.A., 1999. Pathobiology of ischaemic stroke: an integrated view. Trends Neurosci. 22 (9), 391-397. https://doi.org/10.1016/s01662236(99)01401-0.

Eglen, R.M., Wong, E.H., Dumuis, A., Bockaert, J., 1995. Central 5-HT4 receptors. Trends Pharmacol Sci. 16 (11), 391-398. https://doi.org/10.1016/s0165-6147(00)890811.

Feijó Fde, M., Bertoluci, M.C., Reis, C., 2010. Serotonin and hypothalamic control of hunger: a review. Rev Assoc Med Bras. 57 (1), 74-77. https://doi.org/10.1016/ S2255-4823(11)70020-0.

Ferguson, S.S., Zhang, J., Barak, L.S., Caron, M.G., 1996. G-protein-coupled receptor kinases and arrestins: regulators of G-protein-coupled receptor sequestration. Biochem Soc Trans. 24 (4), 953-959. https://doi.org/10.1042/bst0240953.

Fitzpatrick, P.F., 1999. Tetrahydropterin-dependent amino acid hydroxylases. Annu Rev Biochem. 68, 355-381. https://doi.org/10.1146/annurev.biochem.68.1.355.

Flynn, R.W., MacWalter, R.S., Doney, A.S., 2008. The cost of cerebral ischemia. Neuropharmacology. 55 (3), 250-256. https://doi.org/10.1016/j. neuropharm.2008.05.031.

Freedman, N.J., Lefkowitz, R.J., 1996. Desensitization of G protein-coupled receptors. Recent Prog Horm Res. 51, 319-353.

Freund, T.F., Gulyas, A.I., Acsady, L., Gorcs, T., Toth, K., 1990. Serotonergic control of the hippocampus via local inhibitory interneurons. Proc Natl Acad Sci USA. 87, 8501-8505. https://doi.org/10.1073/pnas.87.21.8501.

Fukuyama, N., Takizawa, S., Ishida, H., Hoshiai, K., Shinohara, Y., Nakazawa, H., 1998. Peroxynitrite formation in focal cerebral ischemia-reperfusion in rats occurs predominantly in the peri-infarct region. J Cereb Blood Flow Metab. 18 (2), 123-129. https://doi.org/10.1097/00004647-199802000-00001.

Garcia-Garcia, A.L., Newman-Tancredi, A., Leonardo, E.D., 2014. 5-HT(1A) receptors in mood and anxiety: recent insights into autoreceptor versus heteroreceptor function. Psychopharmacology (Berl). 231 (4), 623-636. https://doi.org/10.1007/s00213013-3389-x.

Gaspar, P., Lillesaar, C., 2012. Probing the diversity of serotonin neurons. Philos Trans R Soc Lond B Biol Sci. 367 (1601), 2382-2394. https://doi.org/10.1098/ rstb.2011.0378.

GBD, 2016. Lifetime Risk of Stroke Collaborators Global, regional, and country-specific lifetime risks of stroke, 1990 and 2016. 2018. N Engl J Med. 379 (25), 2429-2437. https://doi.org/10.1056/NEJMMoa1804492.

Gelderblom, M., Leypoldt, F., Steinbach, K., Behrens, D., Choe, C.U., Siler, D.A., Arumugam, T.V., Orthey, E., Gerloff, C., Tolosa, E., Magnus, T., 2009. Temporal and spatial dynamics of cerebral immune cell accumulation in stroke. Stroke. 40 (5), 1849-1857. https://doi.org/10.1161/STROKEAHA.108.534503.

Gellynck, E., Heyninck, K., Andressen, K.W., Haegeman, G., Levy, F.O., Vanhoenacker, P., Van Craenenbroeck, K., 2013. The serotonin 5-HT7 receptors: two 
decades of research. Exp Brain Res 230 (4), 555-568. https://doi.org/10.1007/ s00221-013-3694-y.

Gennaro, M., Mattiello, A., Pizzorusso, T., 2019. Rodent Models of Developmental Ischemic Stroke for Translational Research: Strengths and Weaknesses. Neural Plast. 2019, 5089321. https://doi.org/10.1155/2019/5089321.

Geri, G., Mongardon, N., Daviaud, F., Empana, J.P., Dumas, F., Cariou, A., 2014 Neurological consequences of cardiac arrest: where do we stand? Ann Fr Anesth Reanim. 33 (2), 98-101. https://doi.org/10.1016/j.annfar.2013.11.003.

Ginsberg, M.D., 2009. Current status of neuroprotection for cerebral ischemia: synoptic overview. Stroke 40 (3 Suppl), S111-S114. https://doi.org/10.1161/ STROKEAHA.108.528877.

Hackett, M.L., Pickles, K., 2014. Part I: frequency of depression after stroke: an updated systematic review and meta-analysis of observational studies. Int J Stroke. 9 (8), 1017-1025. https://doi.org/10.1111/ijs.12357.

Halasy, K., Miettinen, R., Szabat, E., Freund, T.F., 1992. GABAergic interneurons are the major postsynaptic targets of median raphe afferents in the rat dentate gyrus. Eur $\mathrm{J}$ Neurosci. 4, 144-153. https://doi.org/10.1111/j.1460-9568.1992.tb00861.x.

Haleem, D.J., 2019. Targeting Serotonin1A Receptors for Treating Chronic Pain and Depression. Curr Neuropharmacol. 17 (12), 1098-1108. https://doi.org/10.2174/ 1570159X17666190811161807.

Hannon, J., Hoyer, D., 2008. Molecular biology of 5-HT receptors. Behav Brain Res. 195 (1), 198-213. https://doi.org/10.1016/j.bbr.2008.03.020.

Hermann, D.M., Doeppner, T.R., Popa-Wagner, A., 2019. Opportunities and Limitations of Vascular Risk Factor Models in Studying Plasticity-Promoting and Restorative Ischemic Stroke Therapies. Neural Plast. 2019, 9785476. https://doi.org/10.1155/ 2019/9785476.

Hjorth, S., Sharp, T., 1991. Effect of the 5-HT1A receptor agonist 8-OH-DPAT on the release of 5-HT in dorsal and median raphe-innervated rat brain regions as measured by in vivo microdialysis. Life Sci. 48 (18), 1779-1786. https://doi.org/10.1016/ 0024-3205(91)90216-x.

Hoffmann, T., Bennett, S., Koh, C.L., McKenna, K., 2010. A systematic review of cognitive interventions to improve functional ability in people who have cognitive impairment following stroke. Top Stroke Rehabil. 17 (2), 99-107. https://doi.org/10.1310/ tsr1702-99.

Hoyer, D., Clarke, D.E., Fozard, J.R., et al., 1994. International Union of Pharmacology classification of receptors for 5-hydroxytryptamine (Serotonin). Pharmacol Rev. 46 (2), 157-203.

Hsiung, S.C., Tamir, H., Franke, T.F., Liu, K.P., 2005. Roles of extracellular signalregulated kinase and Akt signaling in coordinating nuclear transcription factorkappaB-dependent cell survival after serotonin $1 \mathrm{~A}$ receptor activation. J Neurochem. 95 (6), 1653-1666. https://doi.org/10.1111/j.1471-4159.2005.03496.x.

Jacobs, B.L., Azmitia, E.C., 1992. Structure and function of the brain serotonin system. Physiol Rev. 72 (1), 165-229. https://doi.org/10.1152/physrev.1992.72.1.165.

Johansen, F.F., Hasseldam, H., Nybro Smith, M., Rasmussen, R.S., 2014. Drug-induced hypothermia by 5HT1A agonists provide neuroprotection in experimental stroke: new perspectives for acute patient treatment. J Stroke Cerebrovasc Dis. 23 (10), 2879-2887. https://doi.org/10.1016/j.jstrokecerebrovasdis.2014.07.019.

Johnson, C.O., Nguyen, M., Roth, G.A., et al., 2019. Global, regional, and national burden of stroke, 1990-2016: a systematic analysis for the Global Burden of Disease Study 2016. Lancet Neurol. 18 (5), 439-458. https://doi.org/10.1016/S1474-4422 (19)30034-1.

Justicia, C., Panés, J., Solé, S., Cervera, A., Deulofeu, R., Chamorro, A., Planas, A.M., 2003. Neutrophil infiltration increases matrix metalloproteinase- 9 in the ischemic brain after occlusion/reperfusion of the middle cerebral artery in rats. J Cereb Blood Flow Metab. 23 (12), 1430-1440. https://doi.org/10.1097/01. WCB.0000090680.07515.C8.

Kamei, K., Maeda, N., Ogino, R., et al., 2001. New 5-HT1A receptor agonists possessing 1,4-benzoxazepine scaffold exhibit highly potent anti-ischemic effects. Bioorg Med Chem Lett. 11 (4), 595-598. https://doi.org/10.1016/s0960-894x(01)00008-7.

Khodanovich, M., Kisel, A., 2015. Animal models of cerebral ischemia. AIP Conference Proceedings 1688, 030037. https://doi.org/10.1063/1.4936032.

Kim, I.J., Drahushuk, K.M., Kim, W.Y., et al., 2004. Extracellular signal-regulated kinases regulate dendritic growth in rat sympathetic neurons. J Neurosci. 24 (13), 3304-3312. https://doi.org/10.1523/JNEUROSCI.3286-03.2004.

Kim, D.H., Li, H., Yoo, K.Y., Lee, B.H., Hwang, I.K., Won, M.H., 2007. Effects of fluoxetine on ischemic cells and expressions in BDNF and some antioxidants in the gerbil hippocampal CA1 region induced by transient ischemia. Exp Neurol. 204 (2), 748-758. https://doi.org/10.1016/j.expneurol.2007.01.008.

Kim, Y.R., Kim, H.N., Hong, K.W., Shin, H.K., Choi, B.T., 2016. Anti-depressant effects of phosphodiesterase 3 inhibitor cilostazol in chronic mild stress-treated mice after ischemic stroke. Psychopharmacology (Berl). 233 (6), 1055-1066. https://doi.org/ 10.1007/s00213-015-4185-6.

Kitagawa, K., 2007. CREB and cAMP response element-mediated gene expression in the ischemic brain. FEBS J. 274 (13), 3210-3217. https://doi.org/10.1111/j.17424658.2007.05890.x.

Knapp, P., Campbell Burton, C.A., Holmes, J., Murray, J., Gillespie, D., Lightbody, C.E., Watkins, C.L., Chun, H.Y., Lewis, S.R., 2017. Interventions for treating anxiety after stroke. Cochrane Database Syst Rev. 5 (5), 23. https://doi.org/10.1002/14651858. CD008860. CD008860.

Knowles, M.D., de la Tremblaye, P.B., Azogu, I., Plamondon, H., 2016. Endocannabinoid CB1 receptor activation upon global ischemia adversely impact recovery of reward and stress signaling molecules, neuronal survival and behavioral impulsivity. Prog Neuropsychopharmacol Biol Psychiatry 3 (66), 8-21. https://doi.org/10.1016/j. pnpbp.2015.10.010.

Kukley, M., Schaper, C., Becker, A., Rose, K., Krieglstein, J., 2001. Effect of 5-hydroxytryptamine 1 A receptor agonist BAY X 3702 on BCL-2 and BAX proteins level in the ipsilateral cerebral cortex of rats after transient focal ischaemia. Neuroscience. 107 (3), 405-413. https://doi.org/10.1016/s0306-4522(01)00369-4.

Kushwaha, N., Albert, P.R., 2005. Coupling of 5-HT1A autoreceptors to inhibition of mitogen-activated protein kinase activation via G beta gamma subunit signaling. Eur J Neurosci. 21 (3), 721-732. https://doi.org/10.1111/j.1460-9568.2005.03904.x.

Lawrence, E.S., Coshall, C., Dundas, R., Stewart, J., Rudd, A.G., Howard, R., Wolfe, C.D., 2001. Estimates of the prevalence of acute stroke impairments and disability in a multiethnic population. Stroke. 32 (6), 1279-1284. https://doi.org/10.1161/01. str.32.6.1279.

Lee, C.H., Park, J.H., Yoo, K.Y., Choi, J.H., Hwang, I.K., Ryu, P.D., Kim, D.H., Kwon, Y.G., Kim, Y.M., Won, M.H., 2011. Pre- and post-treatments with escitalopram protect against experimental ischemic neuronal damage via regulation of BDNF expression and oxidative stress. Exp Neurol. 229 (2), 450-459. https://doi.org/10.1016/j. expneurol.2011.03.015.

Lee, C.H., Ahn, J.H., Won, M.H., 2015. New expression of 5-HT1A receptor in astrocytes in the gerbil hippocampal CA1 region following transient global cerebral ischemia. Neurol Sci. 36 (3), 383-389. https://doi.org/10.1007/s10072-014-1958-3.

Leker, R.R., Shohami, E., 2002. Cerebral ischemia and trauma-different etiologies yet similar mechanisms: neuroprotective opportunities. Brain Res Brain Res Rev. 39 (1), 55-73. https://doi.org/10.1016/s0165-0173(02)00157-1.

León-Moreno, L.C., Castañeda-Arellano, R., Rivas-Carrillo, J.D., Dueñas-Jiménez, S.H., 2020. Challenges and Improvements of Developing an Ischemia Mouse Model Through Bilateral Common Carotid Artery Occlusion. J Stroke Cerebrovasc Dis. 29 (5), 104773. https://doi.org/10.1016/j.jstrokecerebrovasdis.2020.104773.

Li, L.X., Cheng, Y.F., Lin, H.B., Wang, C., Xu, J.P., Zhang, H.T., 2011. Prevention of cerebral ischemia-induced memory deficits by inhibition of phosphodiesterase- 4 in rats. Metab Brain Dis. 26 (1), 37-47. https://doi.org/10.1007/s11011-011-9235-0.

Liao, F., Wang, J., He, P., 2008. Multi-resolution entropy analysis of gait symmetry in neurological degenerative diseases and amyotrophic lateral sclerosis. Med Eng Phys. 30 (3), 299-310. https://doi.org/10.1016/j.medengphy.2007.04.014.

Liao, Y., Kristiansen, A.M., Oksvold, C.P., Tuvnes, F.A., Gu, N., Rundén-Pran, E., Ruth, P., Sausbier, M., Storm, J.F., 2010. Neuronal Ca2+-activated K+ channels limit brain infarction and promote survival. PLoS One 5 (12), 30. https://doi.org/10.1371/ journal.pone.0015601 e15601.

Liesz, A., Kleinschnitz, C., 2015. Editorial: Mechanisms of neuroinflammation and inflammatory neurodegeneration in acute brain injury. Front Cell Neurosci. 9, 300. https://doi.org/10.3389/fncel.2015.00300.

Liesz, A., Kleinschnitz, C., 2016. Regulatory T Cells in Post-stroke Immune Homeostasis. Transl Stroke Res. 7 (4), 313-321. https://doi.org/10.1007/s12975-016-0465-7.

Lin, S.L., Setya, S., Johnson-Farley, N.N., Cowen, D.S., 2002. Differential coupling of 5HT(1) receptors to G proteins of the G(i) family. Br J Pharmacol. 136 (7), 1072-1078. https://doi.org/10.1038/sj.bjp.0704809.

Liu, Y.F., Albert, P.R., 1991. Cell-specific signaling of the 5-HT1A receptor. Modulation by protein kinases C and A. J Biol Chem. 266 (35), 23689-23697.

Lladó-Pelfort, L., Assié, M.B., Newman-Tancredi, A., Artigas, F., Celada, P., 2010. Preferential in vivo action of F15599, a novel 5-HT(1A) receptor agonist, at postsynaptic 5-HT(1A) receptors. Br J Pharmacol 160 (8), 1929-1940. https://doi. org/10.1111/j.1476-5381.2010.00738.x.

Maddaloni, G., Bertero, A., Pratelli, M., et al., 2017. Development of Serotonergic Fibers in the Post-Natal Mouse Brain. Front Cell Neurosci. 11, 202. https://doi.org/ 10.3389/fncel.2017.00202.

Mannoury la Cour, C., El Mestikawy, S., Hanoun, N., Hamon, M., Lanfumey, L., 2006. Regional differences in the coupling of 5-hydroxytryptamine-1A receptors to G proteins in the rat brain. Mol Pharmacol. 70 (3), 1013-1021. https://doi.org/ 10.1124/mol.106.022756.

Marco, I., Valhondo, M., Martín-Fontecha, M., et al., 2011. New serotonin 5-HT(1A) receptor agonists with neuroprotective effect against ischemic cell damage. J Med Chem. 54 (23), 7986-7999. https://doi.org/10.1021/jm2007886.

Matsuzaki, H., Tamatani, M., Mitsuda, N., et al., 1999. Activation of Akt kinase inhibits apoptosis and changes in Bcl-2 and Bax expression induced by nitric oxide in primary hippocampal neurons. J Neurochem. 73 (5), 2037-2046.

Mauler, F., Horváth, E., 2005. Neuroprotective efficacy of repinotan HCl, a 5-HT1A receptor agonist, in animal models of stroke and traumatic brain injury. J Cereb Blood Flow Metab. 25 (4), 451-459. https://doi.org/10.1038/sj.jcbfm.9600038.

McCorvy, J.D., Roth, B.L., 2015. Structure and function of serotonin G protein-coupled receptors. Pharmacol Ther. 150, 129-142. https://doi.org/10.1016/j. pharmthera.2015.01.009.

Mehta, M., Ahmed, Z., Fernando, S.S., Cano-Sanchez, P., Adayev, T., Ziemnicka, D., Wieraszko, A., Banerjee, P., 2007a. Plasticity of 5-HT 1A receptor-mediated signaling during early postnatal brain development. J Neurochem. 101 (4), 918-928. https://doi.org/10.1111/j.1471-4159.2007.04448.x.

Mehta, S.L., Manhas, N., Raghubir, R., 2007b. Molecular targets in cerebral ischemia for developing novel therapeutics. Brain Res Rev. 54 (1), 34-66. https://doi.org/ 10.1016/j.brainresrev.2006.11.003.

Meller, E., Goldstein, M., Bohmaker, K., 1990. Receptor reserve for 5-hydroxytryptamine1A-mediated inhibition of serotonin synthesis: possible relationship to anxiolytic properties of 5-hydroxytryptamine1A agonists. Mol Pharmacol. 37 (2), 231-237.

Mishima, K., Hayakawa, K., Abe, K., et al., 2005. Cannabidiol prevents cerebral infarction via a serotonergic 5-hydroxytryptamine1A receptor-dependent mechanism. Stroke. 36 (5), 1077-1082. https://doi.org/10.1161/01. STR.0000163083.59201.34.

Miyazaki, I., Asanuma, M., 2016. Serotonin 1A Receptors on Astrocytes as a Potential Target for the Treatment of Parkinson's Disease. Curr Med Chem. 23 (7), 686-700. https://doi.org/10.2174/0929867323666160122115057. 
Miyazaki, I., Asanuma, M., Murakami, S., et al., 2013. Targeting 5-HT(1A) receptors in astrocytes to protect dopaminergic neurons in Parkinsonian models. Neurobiol Dis. 59, 244-256. https://doi.org/10.1016/j.nbd.2013.08.003.

Mogha, A., Guariglia, S.R., Debata, P.R., Wen, G.Y., Banerjee, P., 2012. Serotonin 1A receptor-mediated signaling through ERK and PKC $\alpha$ is essential for normal synaptogenesis in neonatal mouse hippocampus. Transl Psychiatry. 2 (1), e66 https://doi.org/10.1038/tp.2011.58.

Mori, M.A., Meyer, E., Soares, L.M., Milani, H., Guimarães, F.S., de Oliveira, R.M.W., 2017. Cannabidiol reduces neuroinflammation and promotes neuroplasticity and functional recovery after brain ischemia. Prog Neuropsychopharmacol Biol Psychiatry. 75, 94-105. https://doi.org/10.1016/j.pnpbp.2016.11.005.

Moulaert, V.R., Wachelder, E.M., Verbunt, J.A., Wade, D.T., van Heugten, C.M., 2010 Determinants of quality of life in survivors of cardiac arrest. J Rehabil Med. 42 (6), 553-558. https://doi.org/10.2340/16501977-0547.

National Institute of Neurological Disorders and Stroke rt-PA Stroke Study Group, 1995 Tissue plasminogen activator for acute ischemic stroke. N Engl J Med. 333 (24), 1581-1587. https://doi.org/10.1056/NEJM199512143332401.

Nelson, D.L., 2004. 5-HT5 receptors. Curr Drug Targets CNS Neurol Disord. 3 (1), 53-58. https://doi.org/10.2174/1568007043482606.

Newman-Tancredi, A., 2011. Biased agonism at serotonin 5-HT1A receptors: Preferential postsynaptic activity for improved therapy of CNS disorders. Neuropsychiatry 1 (2), 149-164. https://doi.org/10.2217/npy.11.12.

Newman-Tancredi, A., Kleven, M.S., 2011. Comparative pharmacology of antipsychotics possessing combined dopamine D2 and serotonin 5-HT1A receptor properties. Psychopharmacology (Berl). 216 (4), 451-473. https://doi.org/10.1007/s00213 011-2247-y.

Newman-Tancredi, A., Martel, J.C., Assié, M.B., et al., 2009. Signal transduction and functional selectivity of F15599, a preferential post-synaptic 5-HT1A receptor agonist. Br J Pharmacol. 156 (2), 338-353. https://doi.org/10.1111/j.14765381.2008.00001.x

Nichols, D.E., Nichols, C.D., 2008. Serotonin receptors. Chem Rev. 108 (5), 1614-1641. https://doi.org/10.1021/cr078224o.

Palacios, J.M., 2016. Serotonin receptors in brain revisited. Brain Res. 1645, 46-49. https://doi.org/10.1016/j.brainres.2015.12.042.

Pang, C., Cao, L., Wu, F., Wang, L., Wang, G., Yu, Y., Zhang, M., Chen, L., Wang, W., Lv, W., Chen, L., Zhu, J., Pan, J., Zhang, H., Xu, Y., Ding, L., 2015. The effect of transresveratrol on post-stroke depression via regulation of hypothalamus-pituitaryadrenal axis. Neuropharmacology. 97, 447-456. https://doi.org/10.1016/j. neuropharm.2015.04.017.

Pazos, A., Cortés, R., Palacios, J.M., 1985. Quantitative autoradiographic mapping of serotonin receptors in the rat brain. II. Serotonin-2 receptors. Brain Res. 346 (2), 231-249. https://doi.org/10.1016/0006-8993(85)90857-1.

Peroutka, S., 1988. 5-Hydroxytryptamine Receptor Subtypes. Ann Rev Neurosc. 11, 45-60. https://doi.org/10.1146/annurev.ne.11.030188.000401.

Piera, M.J., Beaughard, M., Michelin, M.T., Massingham, R., 1995. Effects of the 5hydroxytryptamine1A receptor agonists, 8-OH-DPAT, buspirone and flesinoxan, upon brain damage induced by transient global cerebral ischaemia in gerbils. Arch Int Pharmacodyn Ther. 329 (3), 347-359. https://doi.org/10.1016/0006-8993(85) 90857-1.

Pollak Dorocic, I., Fürth, D., Xuan, Y., et al., 2014. A whole-brain atlas of inputs to serotonergic neurons of the dorsal and median raphe nuclei. Neuron. 83 (3), 663-678. https://doi.org/10.1016/j.neuron.2014.07.002.

Polter, A.M., Li, X., 2010. 5-HT1A receptor-regulated signal transduction pathways in brain. Cell Signal. 22 (10), 1406-1412. https://doi.org/10.1016/j. cellsig.2010.03.019.

Povroznik, J.M., Ozga, J.E., Vonder Harr, C., Engler-Chiurazzi, E.B., 2018. Executive (dys)function after stroke: special considerations for behavioral pharmacology. Behav Pharmacol 29 (7), 638-653. https://doi.org/10.1097/ FBP.0000000000000432.

Pratt, G.D., Bowery, N.G., Kilpatrick, G.J., Leslie, R.A., Barnes, N.M., Naylor, R.J., Jones, B.J., Nelson, D.R., Palacids, J.M., Slater, P., et al., 1990. Consensus meeting agrees distribution of 5-HT3 receptors in mammalian hindbrain. Trends Pharmacol Sci. 11 (4), 135-137. https://doi.org/10.1016/0165-6147(90)90058-g.

Prehn, J.H., Backhauss, C., Karkoutly, C., et al., 1991. Neuroprotective properties of 5HT1A receptor agonists in rodent models of focal and global cerebral ischemia. Eur J Pharmacol. 203 (2), 213-222. https://doi.org/10.1016/0014-2999(91)90717-5.

Prehn, J.H., Welsch, M., Backhauss, C., et al., 1993. Effects of serotonergic drugs in experimental brain ischemia: evidence for a protective role of serotonin in cerebral ischemia. Brain Res. 630 (1-2), 10-20. https://doi.org/10.1016/0006-8993(93) 90636-2.

Rajkovic, O., Potjewyd, G., Pinteaux, E., 2018. Regenerative Medicine Therapies for Targeting Neuroinflammation After Stroke. Front Neurol. 9, 734. https://doi.org/ 10.3389/fneur.2018.00734.

Rajsic, S., Gothe, H., Borba, H.H., et al., 2019. Economic burden of stroke: a systematic review on post-stroke care. Eur J Health Econ. 20 (1), 107-134. https://doi.org/ 10.1007/s10198-018-0984-0.

Raval, A.P., Liu, C., Hu, B.R., 2009. Rat Model of Global Cerebral Ischemia: The TwoVessel Occlusion (2VO) Model of Forebrain Ischemia. In: Chen, J., Xu, Z.C., Xu, X.M., Zhang, J.H. (Eds.), Animal Models of Acute Neurological Injuries. Springer Protocols Handbooks, Humana Press. https://doi.org/10.1007/978-1-60327-185-1_7.

Raymond, J.R., Mukhin, Y.V., Gettys, T.W., Garnovskaya, M.N., 1999. The recombinant 5-HT1A receptor: G protein coupling and signalling pathways. Br J Pharmacol. 127 (8), 1751-1764. https://doi.org/10.1038/sj.bjp.0702723.

Riad, M., Garcia, S., Watkins, K.C., Jodoin, N., Doucet, E., Langlois, X., el Mestikawy, S., Hamon, M., Descarries, L., 2000. Somatodendritic localization of 5-HT1A and preterminal axonal localization of 5-HT1B serotonin receptors in adult rat brain. J Comp Neurol. 417, 181-194.

Rojas, P.S., Fiedler, J.L., 2016. What Do We Really Know About 5- $\mathrm{HT}_{1 \mathrm{~A}}$ Receptor Signaling in Neuronal Cells? Front Cell Neurosci. 10, 272. https://doi.org/10.3389/ fncel.2016.00272.

Roth, B.L., Berry, S.A., Kroeze, W.K., Willins, D.L., Kristiansen, K., 1998. Serotonin 5HT2A receptors: molecular biology and mechanisms of regulation. Crit Rev Neurobiol. 12 (4), 319-338. https://doi.org/10.1615/critrevneurobiol.v12.i4.30.

Salazar-Colocho, P., Del Río, J., Frechilla, D., 2007. Serotonin 5-hT1A receptor activation prevents phosphorylation of NMDA receptor NR1 subunit in cerebral ischemia. J Physiol Biochem. 63 (3), 203-211. https://doi.org/10.1007/BF03165783.

Salazar-Colocho, P., Del Río, J., Frechilla, D., 2008. Neuroprotective effects of serotonin 5-HT 1A receptor activation against ischemic cell damage in gerbil hippocampus: Involvement of NMDA receptor NR1 subunit and BDNF. Brain Res. 1199, 159-166. https://doi.org/10.1016/j.brainres.2007.12.032.

Salminen, A., Liu, P.K., Hsu, C.Y., 1995. Alteration of transcription factor binding activities in the ischemic rat brain. Biochem Biophys Res Commun. 212 (3), 939-944. https://doi.org/10.1006/bbrc.1995.2060.

Santarelli, L., Saxe, M., Gross, C., et al., 2003. Requirement of hippocampal neurogenesis for the behavioral effects of antidepressants. Science. 301 (5634), 805-809. https:// doi.org/10.1126/science.1083328.

Sasaki, T., Kitagawa, K., Omura-Matsuoka, E., et al., 2007. The phosphodiesterase inhibitor rolipram promotes survival of newborn hippocampal neurons after ischemia. Stroke. 38 (5), 1597-1605. https://doi.org/10.1161/ STROKEAHA.106.476754.

Schäbitz, W.R., Schwab, S., Spranger, M., Hacke, W., 1997. Intraventricular brainderived neurotrophic factor reduces infarct size after focal cerebral ischemia in rats. J Cereb Blood Flow Metab. 17 (5), 500-506. https://doi.org/10.1097/00004647199705000-00003.

Schaper, C., Zhu, Y., Kouklei, M., Culmsee, C., Krieglstein, J., 2000. Stimulation of 5-HT (1A) receptors reduces apoptosis after transient forebrain ischemia in the rat. Brain Res. 883 (1), 41-50. https://doi.org/10.1016/s0006-8993(00)02876-6.

Schmid, C.L., Raehal, K.M., Bohn, L.M., 2008. Agonist-directed signaling of the serotonin 2A receptor depends on beta-arrestin-2 interactions in vivo. Proc Natl Acad Sci U S A. 105 (3), 1079-1084. https://doi.org/10.1073/pnas.0708862105.

Semkova, I., Wolz, P., Krieglstein, J., 1998. Neuroprotective effect of 5-HT1A receptor agonist, Bay X 3702, demonstrated in vitro and in vivo. Eur J Pharmacol. 359 (2-3), 251-260. https://doi.org/10.1016/s0014-2999(98)00634-7.

Senda, D.M., Franzin, S., Mori, M.A., de Oliveira, R.M., Milani, H., 2011. Acute, postischemic sensorimotor deficits correlate positively with infarct size but fail to predict its occurrence and magnitude after middle cerebral artery occlusion in rats. Behav Brain Res. 216 (1), 29-35. https://doi.org/10.1016/j.bbr.2010.06.026.

Sharp, T., Barnes, N.M., 2020. Central 5-HT receptors and their function; present and future. Neuropharmacology 15, 177. https://doi.org/10.1016/j. neuropharm.2020.108155, 108155.

Sniecikowska, J., Newman-Tancredi, A., Kolaczkowski, M., 2019. From Receptor Selectivity to Functional Selectivity: The Rise of Biased Agonism in 5-HT1A Receptor Drug Discovery. Curr Top Med Chem. 19 (26), 2393-2420. https://doi.org/10.2174/ 1568026619666190911122040.

Soares, L.M., De Vry, J., Steinbusch, H.W.M., Milani, H., Prickaerts, J., Weffort de Oliveira, R.M., 2016. Rolipram improves cognition, reduces anxiety- and despair-like behaviors and impacts hippocampal neuroplasticity after transient global cerebral ischemia. Neuroscience. 326, 69-83. https://doi.org/10.1016/j. neuroscience.2016.03.062.

Sprouse, J.S., Aghajanian, G.K., 1986. (-)-Propranolol blocks the inhibition of serotonergic dorsal raphe cell firing by 5-HT1A selective agonists. Eur J Pharmacol. 128 (3), 295-298. https://doi.org/10.1016/0014-2999(86)90782-x.

Tajiri, N., Dailey, T., Metcalf, C., et al., 2013. In vivo animal stroke models: a rationale for rodent and non-human primate models. Transl Stroke Res. 4 (3), 308-321. https://doi.org/10.1007/s12975-012-0241-2.

Tamatani, M., Ogawa, S., Niitsu, Y., Tohyama, M., 1998. Involvement of Bcl-2 family and caspase-3-like protease in NO-mediated neuronal apoptosis. J Neurochem. 71 (4), 1588-1596. https://doi.org/10.1046/j.1471-4159.1998.71041588.x.

Teal, P., Silver, F.L., Simard, D., 2005. The BRAINS study: safety, tolerability, and dosefinding of repinotan in acute stroke. Can J Neurol Sci. 32 (1), 61-67. https://doi.org/ $10.1017 /$ s0317167100016899.

Teal, P., Davis, S., Hacke, W., et al., 2009. A randomized, double-blind, placebocontrolled trial to evaluate the efficacy, safety, tolerability, and pharmacokinetic/ pharmacodynamic effects of a targeted exposure of intravenous repinotan in patients with acute ischemic stroke: modified Randomized Exposure Controlled Trial (mRECT). Stroke. 40 (11), 3518-3525. https://doi.org/10.1161/ STROKEAHA.109.551382.

Thomas, D.R., Hagan, J.J., 2004. 5-HT7 receptors. Curr Drug Targets CNS Neurol Disord. 3 (1), 81-90. https://doi.org/10.2174/1568007043482633.

Tingley, W.G., Ehlers, M.D., Kameyama, K., et al., 1997. Characterization of protein kinase $\mathrm{A}$ and protein kinase $\mathrm{C}$ phosphorylation of the $\mathrm{N}$-methyl-D-aspartate receptor NR1 subunit using phosphorylation site-specific antibodies. J Biol Chem. 272 (8), 5157-5166. https://doi.org/10.1074/jbc.272.8.5157.

Torup, L., Møller, A., Sager, T.N., Diemer, N.H., 2000. Neuroprotective effect of 8-OHDPAT in global cerebral ischemia assessed by stereological cell counting. Eur J Pharmacol. 395 (2), 137-141. https://doi.org/10.1016/s0014-2999(00)00175-8.

Traystman, R.J., 2003. Animal models of focal and global cerebral ischemia. ILAR J. 44 (2), 85-95. https://doi.org/10.1093/ilar.44.2.85.

van Goethem, N.P., Schreiber, R., Newman-Tancredi, A., Varney, M., Prickaerts, J., 2015. Divergent effects of the 'biased' 5-HT1 A receptor agonists F15599 and F13714 in a 
novel object pattern separation task. Br J Pharmacol. 172 (10), 2532-2543. https:// doi.org/10.1111/bph.13071.

van Rooij, F.G., Schaapsmeerders, P., Maaijwee, N.A., van Duijnhoven, D.A., de Leeuw, F.E., Kessels, R.P., van Dijk, E.J., 2014. Persistent cognitive impairment after transient ischemic attack. Stroke. 45 (8), 2270-2274. https://doi.org/10.1161/ STROKEAHA.114.005205.

Veerbeek, J.M., Kwakkel, G., van Wegen, E.E., Ket, J.C., Heymans, M.W., 2011. Early prediction of outcome of activities of daily living after stroke: a systematic review. Stroke. 42 (5), 1482-1488. https://doi.org/10.1161/STROKEAHA.110.604090.

Verge, D., Daval, G., Patey, A., Gozlan, H., el Mestikawy, S., Hamon, M., 1985. Presynaptic 5-HT autoreceptors on serotonergic cell bodies and/or dendrites but not terminals are of the 5-HT1A subtype. Eur J Pharmacol. 113 (3), 463-464. https:// doi.org/10.1016/0014-2999(85)90099-8.

Violin, J.D., Crombie, A.L., Soergel, D.G., Lark, M.W., 2014. Biased ligands at G-protein coupled receptors: promise and progress. Trends Pharmacol Sci. 35 (7), 308-316. https://doi.org/10.1016/j.tips.2014.04.007.

Walther, D.J., Peter, J.U., Bashammakh, S., et al., 2003. Synthesis of serotonin by a second tryptophan hydroxylase isoform. Science. 299 (5603), 76. https://doi.org/ 10.1126/science.1078197.

Wang, R.Y., Aghajanian, G.K., 1977. Inhibiton of neurons in the amygdala by dorsal raphe stimulation: mediation through a direct serotonergic pathway. Brain Res. 120 (1), 85-102. https://doi.org/10.1016/0006-8993(77)90499-1.

Whitaker-Azmitia, P.M., Clarke, C., Azmitia, E.C., 1992. 5-HT1A immunoreactivity in brain astrocytes co-localized with GFAP. Synapse 14, 201-205.
Woolley, M.L., Marsden, C.A., Fone, K.C., 2004. 5-ht6 receptors. Curr Drug Targets CNS Neurol Disord. 3 (1), 59-79. https://doi.org/10.2174/1568007043482561.

Wu, D., Pardridge, W.M., 1999. Neuroprotection with noninvasive neurotrophin delivery to the brain. Proc Natl Acad Sci U S A. 96 (1), 254-259. https://doi.org/10.1073/ pnas.96.1.254.

Xu, T., Pandey, S.C., 2000. Cellular localization of serotonin(2A) (5HT(2A)) receptors in the rat brain. Brain Res Bull. 51 (6), 499-505. https://doi.org/10.1016/s0361-9230 (99)00278-6.

Yamaguchi, A., Tamatani, M., Matsuzaki, H., et al., 2001. Akt activation protects hippocampal neurons from apoptosis by inhibiting transcriptional activity of p53. J Biol Chem. 276 (7), 5256-5264. https://doi.org/10.1074/jbc.M008552200.

Yamaguchi, A., Jitsuishi, T., Hozumi, T., Iwanami, J., Kitajo, K., Yamaguchi, H., Mori, Y., Mogi, M., Sawai, S., 2020. Temporal expression profiling of DAMPs-related genes revealed the biphasic post-ischemic inflammation in the experimental stroke model. Mol Brain 7 (1), 57. https://doi.org/10.1186/s13041-020-00598-1, 13.

Zaitseva, T., Schears, G., Schultz, S., et al., 2005. Circulatory arrest and low-flow cardiopulmonary bypass alter CREB phosphorylation in piglet brain. Ann Thorac Surg. 80 (1), 245-250. https://doi.org/10.1016/j.athoracsur.2005.02.016.

Zhao, Y., Xiao, M., He, W., Cai, Z., 2015. Minocycline upregulates cyclic AMP response element binding protein and brain-derived neurotrophic factor in the hippocampus of cerebral ischemia rats and improves behavioral deficits. Neuropsychiatr Dis Treat. 26 (11), 507-516. https://doi.org/10.2147/NDT.S73836. 